\title{
Fydrology of the Alluvium
}

of the Arkansas River,

\section{Yuskogee, Oklahoma, to}

\section{Tort Smith, Arkansas}

. $y$ HARRY H. TANAKA and JERRALD R. HOLLOWELL

With a section on

'SHEMICAL QUALITY OF THE WATER

Ry JOHN J. MURPHY

CONTRIBUTIONS TO THE HYDROLOGY OF THE UNITED STATES

GEOLOGICAL SURVEY WATER-SUPPLY PAPER 1809-T

Drepared in cooperation with the

J.S. Army Corps of Engineers

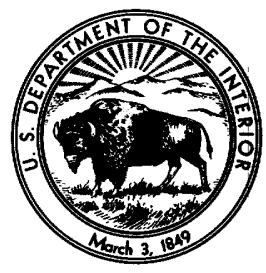




\section{UNITED STATES DEPARTMENT OF THE INTERIOR}

STEWART L. UDALL, Secretary

\section{GEOLOGICAL SURVEY}

William T. Pecora, Director 


\section{CONTENTS}

\begin{tabular}{|c|c|}
\hline & \\
\hline Abstract. & T1 \\
\hline troductio & 2 \\
\hline Purpose and scope of the investigation & 2 \\
\hline extent of the area & \\
\hline tigations_- & \\
\hline of investigation & \\
\hline Well-numbering system & \\
\hline Acknowledgments & \\
\hline Geography & \\
\hline ce features and drainage & \\
\hline - & \\
\hline on-16-1 & \\
\hline$y$, and mineral resources. & \\
\hline operties of the rocks & \\
\hline $\mathrm{k}_{-1}$ & 0 \\
\hline deposits & \\
\hline n & 2 \\
\hline - & 4 \\
\hline cen & 4 \\
\hline properties.-1 & 6 \\
\hline 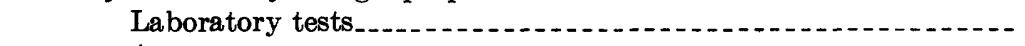 & 16 \\
\hline 思 & 8 \\
\hline and field data.... & \\
\hline the piezometric surface & \\
\hline ement, & 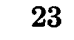 \\
\hline ( & 23 \\
\hline . & 27 \\
\hline - & 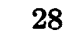 \\
\hline מ & 28 \\
\hline 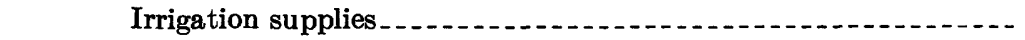 & 8 \\
\hline blic supplies. & 29 \\
\hline stock supplies & 30 \\
\hline ble for development of ground water...... & 30 \\
\hline , by John J. Murphy & 31 \\
\hline ditions on the hydrologic system of the alluvium. & 39 \\
\hline ( & 41 \\
\hline 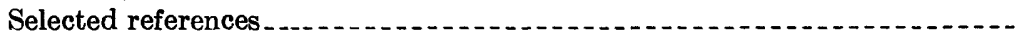 & \\
\hline
\end{tabular}




\section{ILLUSTRATIONS}

[Plates are in pocket]

Plate 1. Geologic map and sections of the Arkansas River valley between Muskogee and Fort Smith.

2. Hydrologic map of the Arkansas River valley between Muskogee and Fort Smith showing wells and piezometric contours.

3. Hydrologic map of the Arkansas River valley between Muskogee and Fort Smith showing areas favorable for development of ground water.

Figure 1. Index map of eastern Oklahoma showing report area

2. Sketch of well-numbering system . .

3. Graph of cumulative departure from average precipitation at Webbers Falls.

4. Graph showing relation of median grain size to permeability.-

5. Hydrographs of wells in a profile normal to the Arkansas River

6. Graph showing height of water-level rises at distances from the river

\section{TABLES}

TABLE 1. Population, by communities, in the Arkansas River valley---

2. Physical and hydrologic properties of the alluvium

3. Summary of the coefficients of transmissibility, permeability, and storage determined by aquifer tests

4. Permeabilities of the alluvium of the Arkansas River valley --

5. Recharge and discharge in selected areas of the Arkansas River valley

6. Chemical analyses of water from wells in the alluvium along the Arkansas River between Muskogee and Fort Smith.--

7. Maximum, minimum, and modal concentrations of chemical constituents in water from the alluvium between Muskogee and Fort Smith. 


\title{
CONTRIBUTIONS TO THE HYDROLOGY OF THE UNITED STATES
}

\section{HYDROLOGY OF THE ALLUVIUM OF THE ARKANSAS RIVER, MUSKOGEE, OKLAHOMA, TO FORT SMITH, ARKANSAS}

\author{
By Harry H. Tanaka and Jerrald R. Hollowell
}

\begin{abstract}
The alluvium along 110 miles of the Arkansas River between Muskogee, Okla., and Fort Smith, Ark., is the most important aquifer in this area.

The bedrock, which borders in part and underlies all the alluvial deposits, is well indurated thin- to massive-bedded sandstone, shale, siltstone, and limestone of Mississippian and Pennsylvanian age. The bedrock yields only a small amount of water to domestic and stock wells.

Terrace deposits, whose upper surfaces range from 20 to 120 feet above the flood plain, border the alluvium in segments on both sides of the Arkansas River. The deposits are composed mainly of silt, fine sand, and small amounts of coarse sand and gravel near the base. The terrace deposits yield small to moderate supplies of water to domestic and stock wells.

The alluvium is the most important aquifer along the Arkansas River. It is formed in segments 1-3 miles wide and 3-11 miles long, the total area being about 140 square miles. The grain size of the alluvium generally ranges from gravel and coarse sand near the base to silt or clay near the surface. The total thickness averages 42 feet and the saturated thickness 25 feet. Recharge, mainly from precipitation, is estimated to average 9 inches, or about 67,000 acre-feet, per year. The amount of recharge from adjoining terrace deposits or bedrock is only a small fraction of the total recharge to the alluvium. Natural discharge is mainly by seepage into streams and by evapotranspiration. Discharge by pumpage was estimated to be about 1,700 acre-feet in 1962 . Under average conditions the alluvium has a storage capacity of about 450,000 acre-feet of water. In large areas that are potentially favorable for development of ground water, wells will yield as much as $600 \mathrm{gpm}$ (gallons per minute).

The ground water in the alluvium is predominantly of the calcium, magnesium bicarbonate type, variable in dissolved-solids content, and hard. The quality is affected by the geology, water movement, and hydraulics of the alluvium. The water is suitable for irrigation and for domestic, stock, and limited industrial purposes.
\end{abstract}

A change in the river regimen as a result of the navigation project will raise water levels in the alluvium in most areas and lower it in others. This change 
will alter the recharge-discharge relation in the alluvium, but the changes in most places will increase the potential ground-water resource.

\section{INTRODUCTION}

\section{PURPOSE AND SCOPE OF THE INVFSTIGATION}

The investigation on which this report is based is part of a cooperative program by the U.S. Army Corps of Engineers and the U.S. Geological Survey to study the ground water in the alluvium and to provide information which can be used as a basis for comparing ground-water conditions prior to and after completion of a series of navigation locks and dams on the Arkansas River from its mouth in southeast Arkansas to Muskogee, Okla., and on the Verdigris River from its mouth near Muskogee to Catoosa, Okla.

This report includes basic data obtained from a part of the study. Its purpose is to provide geologic and hydrologic information that can guide the development of ground water in alluvial deposits bordering the Arkansas River between Muskogee, Okla., and Fort Smith, Ark. The report is primarily concerned with the alluvium, the largest source of ground water available along the Arkansas River. The bedrock and terrace deposits bordering the valley have little groundwater potential and are described only briefly. The quality of the ground water was studied to determine its relation to the hydrologic system and to evaluate the suitability of the water for various uses. Future changes in the hydrology of the alluvium resulting from changes in the river regimen are discussed in general terms.

\section{LOCATION AND EXTENT OF THE AREA}

The project area between Muskogee, Okla., and Fort Smith, Ark., includes the flood plain of the Arkansas River and the adjacent terrace deposits and bedrock formations. In this area (fig. 1) the Arkansas River traverses the Interior Highlands of Oklahoma. The rocks of the Interior Highlands are relatively resistant to erosion and generally confine the Arkansas River flood plain to a width of 1-3 miles. Bedrock, which in places borders the river on one or both sides, separates the flood plain into a series of distinct segments ranging in length from 3 to 11 miles. Consolidated rocks and poorly indurated terrace deposits form the valley walls that rise abruptly 50 to more than 100 feet above the flood plain. Structural features and erosion have produced a series of alternating ridges and valleys in the bedrock which generally parallel the Arkansas River. 


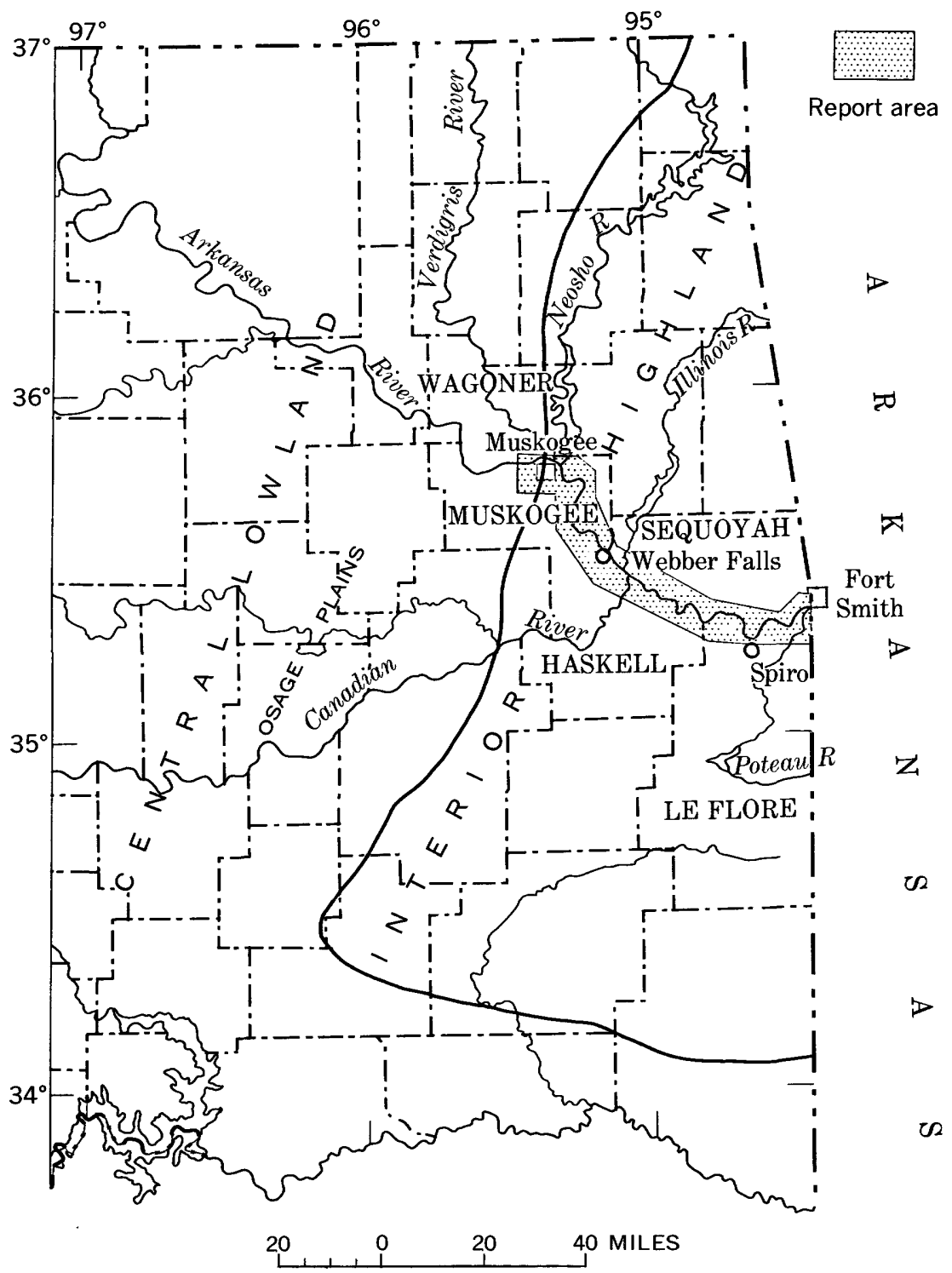

FIGURE 1.-Index map of eastern Oklahoma showing report area.

\section{PREVIOUS INVESTIGATIONS}

Several earlier investigations of the geology and water resources of parts of the project and adjacent areas have proved helpful in the preparation of this report. 
Wilson (1937) included a short study of water resources in a geologic investigation of parts of Muskogee and McIntosh Counties. Oakes and Knechtel (1948) primarily described the coal resources and the stratigraphic sections in Haskell County. Knechtel (1949) described the coal and natural gas resources of northern LeFlore County and included a description of the stratigraphic section of the area. Schoff and Reed (1951) made a detailed investigation of the ground water in the alluvium of the Arkansas River near. Fort Gibson. Huffman (1958) described the geology and presented numerous measured sections and stratigraphic descriptions of the formations that border the Arkansas valley on the north.

\section{METHODS OF INVESTIGATION}

The data used in this report were collected in 1957-62.

Information including total depth, depth to water, and yield of domestic, stock, and irrigation wells was obtained from farmers and county agricultural agents. Data on the geologic and hydrologic properties of the alluvium were obtained from 250 observation wells augured in the alluvium and adjacent terrace deposits and cased with $11 / 4^{-}$and $3 / 4$-inch pipe; 67 test holes were augured for additional geologic information.

The permeability, porosity, specific yield, and grain size of samples collected at 18 sites were determined by laboratory analysis. Aquifer tests to determine transmissibility and storage coefficients of the alluvium were made at six locations.

All observation wells were measured quarterly in a "mass measurement" during 1958, 1959, and part of 1960; from 1960 through 1962, all wells were measured semiannually. Measurements were made at monthly intervals in 62 wells along lines perpendicular to the river in order to relate fluctuations of ground-water levels to river stage and precipitation. Twelve large-diameter, wells were drilled for the installation of instruments to record continuous water-level fluctuations.

Water samples collected from wells were analyzed in the U.S. Geological Survey laboratory in Oklahoma City.

Four gaging stations operated by the Corps of Engineers and one station operated by the U.S. Weather Bureau provided daily stage readings on the Arkansas River. These stations are on bridges crossing the river at Muskogee, Webbers Falls, U.S. Highway 59, Redlands, and Van Buren, Ark. Daily stage readings at Fort Smith were computed from stage-relation curves from the station at Van Buren. 


\section{WELL-NOMBERING SYSTEM}

Wells and test holes are numbered in this report according to their location with respect to the Federal land-survey system used in Oklahoma. The first numeral indicates the township, the second the range, and the third the section in which the well is located. The lowercase letters that follow the section number indicate the position of the well within the section; the first letter indicates the quarter section (160acre tract); the second letter, the quarter-quarter section (40-acre tract) ; and the third letter, the quarter-quarter-quarter section (10acre tract). These letters are assigned in a counterclockwise direction, beginning with " $\mathrm{a}$ " in the northeast quarter. Within each 10acre tract the wells are numbered serially, as indicated by the final digit of the number. Thus well $12 \mathrm{~N}-20 \mathrm{E}-13 \mathrm{bcb} 1$ is the first well to be listed in the NW1/4 SW1/4 NW1/4 of sec. 13, T. 12 N., R. 20 E. (fig. 2 ).

\section{ACKNOWLEDGMENTS}

The authors acknowledge the cooperation and assistance by residents, well owners, and public officials in the area for providing information on wells and in granting permission to drill test holes and to conduct aquifer tests on private and public property, and the aid furnished by the U.S. Army Corps of Engineers, Tulsa District, in the continuing program of ground-water investigations along the Arkansas and Verdigris Rivers.

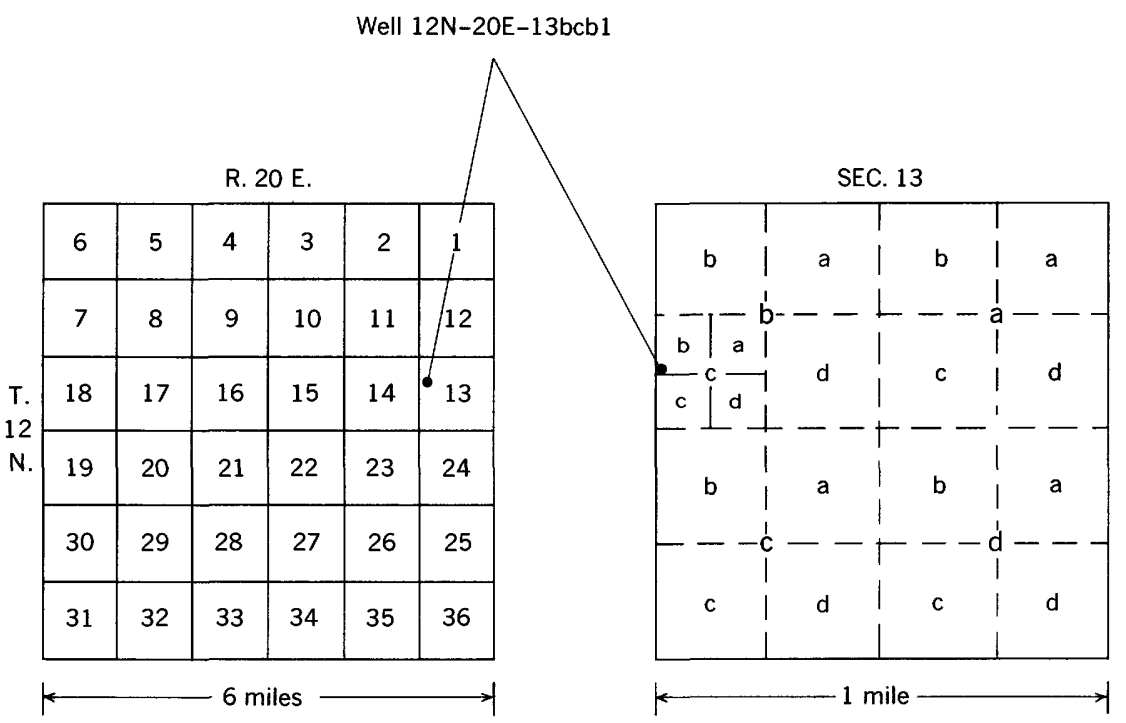

Figure 2.-Well-numbering system. 


\section{GEOGRAPHY}

\section{SURFACE FEATURES AND DRAINAGE}

The Arkansas River rises in the Rocky Mountains of Colorado and flows generally southeast through the Great Plains to Muskogee, Okla. From Muskogee to Little Rock, Ark., it flows through a mountainous section of the Ouachita province. From Little Rock it flows across the relatively flat Coastal Plain to the Mississippi River. The area described in this report lies almost entirely within the Ouachita province in Oklahoma. The Ouachita province is characterized by leveltopped subparallel east-west ridges rising as much as 400 feet above adjacent valley floors. The location and formation of the topographic features have been controlled by the type and attitude of the rock strata. Where the strata are nearly horizontal, broad-topped mountains or conical hills were formed. Where the strata are tilted, ridges have been formed along the outcropping resistant sandstone beds, and valleys have been formed along less resistant shale outcrops. In general, the area is underlain by beds of sandstone and shale dipping gently southwest.

The uplands are drained by five rivers and numerous creeks that enter the Arkansas River between Muskogee and Fort Smith. The Verdigris and Neosho Rivers enter from the north near Muskogee, the Illinois River enters from the northeast, the Canadian River enters from the southwest near Webbers Falls, and the Poteau River enters from the south near Fort Smith. Larger tributary creeks draining the uplands include Dirty Creek, Sallisaw Creek, and San Bois Creek (fig. 1).

The terrace deposits were formed by streams whose base levels were higher than those of present-day streams. The deposits have since been dissected by erosion and occur as isolated patches a few acres to several square miles in area. In some of the larger areas the relief formed on the deposits by erosion exceeds 50 feet, but most of the terrace deposits form relatively flat farmlands.

The flood plain bordering the Arkansas River is covered by a complex pattern of abandoned channels, channel fills, backswamps, natural levees, and point bars. These features are readily identified on aerial photographs and on topographic maps by their vegetation, drainage pattern, and topographic expression.

Recently abandoned channels generally are long, crescent-shaped lakes or depressions. Older channels, which have become partly or completely filled with sediment as a result of repeated floods, form long curved depressions that commonly are 5-20 feet below the adjacent land. In most places the old abandoned channels are covered 
by dense growths of vegetation. Backswamps are low-lying areas flooded during times of high water and bordered by natural levees. Natural levees are lenslike ridges along and parallel to the banks of present and former channels. They slope steeply on the side facing the channel but characteristically slope gently away from the channel toward the adjacent backswamp areas. Point bars are characterized by a series of low, narrow swales and somewhat broader ridges which generally conform to the curvature of the channel bends. Surface drainage in areas covered by point bars is by small streams and sloughs. which follow the larger swales and unite at one or more points near. the downstream ends of the point bar.

\section{CLIMATE}

The climate of the Arkansas River valley of eastern Oklahoma is characterized by small variations in seasonal and yearly temperature and precipitation averages. The mean annual temperature at Webbers Falls is $61.5^{\circ} \mathrm{F}$ and the mean annual precipitation is 44.30 inches. During the 62-year period of record at Webbers Falls, the highest recorded temperature was $115^{\circ} \mathrm{F}$ and the lowest $15^{\circ} \mathrm{F}$ below zero; the greatest yearly precipitation was 72.00 inches in 1945 and the least was 20.17 inches in 1936. The mean monthly precipitation for May, the wettest month, is 5.8 inches; for July, the driest month, the mean monthly precipitation is 2.6 inches. The winters generally are mild. The mean annual snowfall at Webbers Falls is 4.7 inches. Snow occurs most frequently during January and February; the snowfall of an average storm generally is less than 2 inches. The average frost-free period is 224 days and the minimum recorded is 212 days.

Figure 3 shows the monthly precipitation and cumulative departure from average precipitation at Webbers Falls. The average monthly precipitation is computed for the period 1899-1962, and monthly deficiencies or excesses with respect to this average have been added progressively for the period 1948-62. The downward trend of the cumulative-departure curve from 1952 through 1956 results from a deficiency of more than 40 inches from average precipitation; the upward trend of the curve from 1957 through 1961 results from an excess of more than 30 inches from average precipitation.

\section{POPULATION}

The rural and urban population in the report area is concentrated in small communities in the uplands on either side of the Arkansas River flood plain. The population on the flood plain is estimated to be about 1,500, of which more than half is concentrated near Webbers Falls and Fort Smith. Muskogee and Fort Smith, the larger cities 


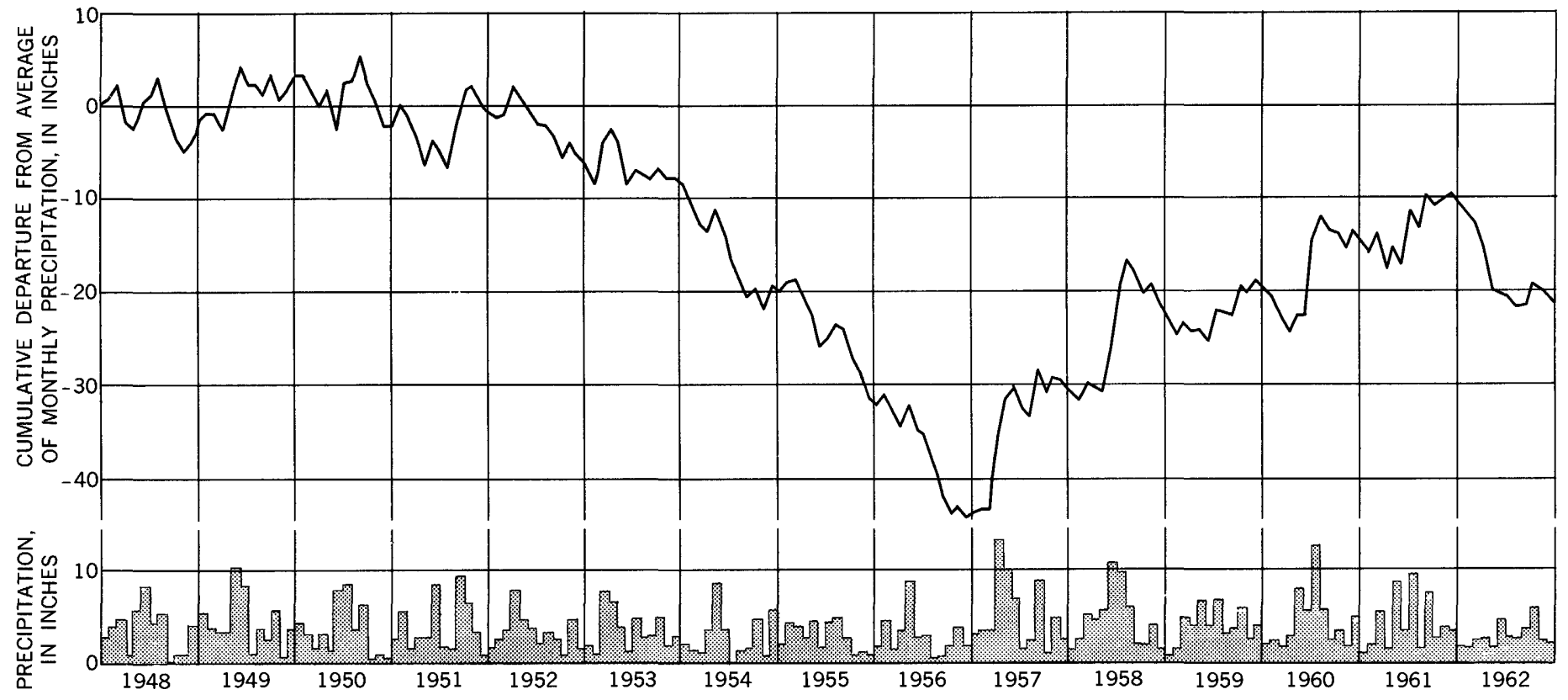

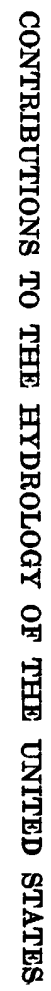


in the project area have shown substantial gains in population during the past 20 years. The rural and urban population in other parts of the area, with the exception of Spiro, has shown a decrease or little change. Census data for communities in or near the project area are shown in table 1 .

TABLE 1.-Population, by communities, in the Arkansas River valley

[From U.s. Bureau of Census]

\begin{tabular}{|c|c|c|c|}
\hline \multirow{2}{*}{ City or town } & \multicolumn{3}{|c|}{ Year } \\
\hline & 1940 & 1950 & 1960 \\
\hline $\begin{array}{l}\text { Fort Smith } \\
\text { Muskogee } \\
\text { Spiro } \\
\text { Fort Gibson } \\
\text { Webbers Falls } \\
\text { Moffett. } \\
\text { Gore } \\
\text { Braggs_. }\end{array}$ & $\begin{array}{r}36,584 \\
32,332 \\
1,041 \\
1,233 \\
486 \\
538 \\
334 \\
392\end{array}$ & $\begin{array}{r}47,942 \\
37,289 \\
1,365 \\
1,496 \\
489 \\
380 \\
387 \\
\mathbf{3 7 4}\end{array}$ & $\begin{array}{r}52,991 \\
38,059 \\
1,450 \\
1,407 \\
441 \\
357 \\
334 \\
\mathbf{3 3 9}\end{array}$ \\
\hline
\end{tabular}

\section{AGRICULTURE, INDUSTRY, AND MINERAL RESOURCES}

The agricultural economy of the flood plain is characterized by farms averaging more than 200 acres, of which nearly all is under cultivation. The flood plain is intensively cultivated and almost half the land is double-cropped in most years. The principal crops are wheat, cotton, soybeans, alfalfa, corn, and produce-largely beans and spinach. Upland areas bordering the valley are utilized chiefly as pasture for livestock.

The Arkansas River valley is favorably located with respect to market facilities. Canneries are at Spiro, Okla., and at several nearby towns in Arkansas. Local market outlets are at Muskogee and Fort Smith, the larger markets readily accessible by highways and railways.

The agricultural economy of the flood plain is not dependent upon irrigation, although it is aided by supplemental irrigation during the hot summer months at the peak of the growing season. The advantages of supplemental irrigation have been increasingly recognized by the farmers; hence, a few new irrigation wells are constructed each year.

Most industry along the Arkansas River valley is concentrated in the larger cities and has little direct bearing on the economy of the rural areas. The only industries dependent upon the agricultural economy are the canneries, an alfalfa-dehydrating mill, and a fertilizer plant.

Mineral resources in or near the valley include natural gas, coal, sand, and gravel. Natural gas is recovered from the Cartersville 
field in Tps. 9 and 10 N., Rs. 24, 25, and 26 E. Coal occurs in at least two bedrock formations that crop out along the valley margins. Sand and gravel are dredged from the bed of the Arkansas River north of Muskogee, and gravel is mined along the banks of the Neosho River near Fort Gibson. Most of the sand and gravel used locally for construction purpases is derived from these sources.

\section{GEOLOGY AND WATER-BEARING PROPERTIES OF THE ROCKS}

\section{BEDROCK}

The term "bedrock" is used in this report to include all consolidated sedimentary rocks of Mississippian and Pennsylvanian age that border or lie beneath the alluvial deposits of the Arkansas River between Muskogee and Fort Smith. The distribution of the bedrock in relation to the alluvial deposits is shown on plate 1.

The bedrock is made up of well-indurated thin- to massive-bedded sandstone, shale, siltstone, and limestone. The sandstone beds are hard and well cemented; their permeability is dependent on joints in the rock, on the weathered zone near the surface, and locally on primary porosity. The shale and siltstone are compact and dense, and permeabilities are determined by fracture zones. The limestone is dense and crystalline, and permeability is dependent on joints in the rock and locally on solution channels. Because its permeability is low in most of the area, the bedrock functions chiefly as a container for the alluvium and the water in it.

The bedrock includes, in ascending order, the Moorefield Formation, Hindsville Limestone, Fayetteville Shale, and Pitkin Limestone of Late Mississippian age; and the Hale and Bloyd Formations, of Early Pennsylvanian age, the Atoka Formation, Hartshorne Sandstone, McAlester Formation, Savanna Formation, and Boggy Shale of Middle Pennsylvania age. Detailed descriptions of these rocks are given by Wilson (1937), Oakes and Knechtel (1948), Knechtel (1949), and Huffman (1958).

The transmissibility of the bedrock is low, but a small amount of water is produced from each geologic formation throughout the report area for domestic and stock use. According to the Oklahoma State Mineral Survey (1937), many domestic wells along the Arkansas River produce water from shale, even though shale ordinarily is too impermeable to transmit usable quantities of water to wells. Faults and folds in the bedrock are common in the area between Muskogee and Fort Smith, and some water probably is being transmitted to wells from fracture zones. Depths to water measured in 25 wells in 
the bedrock range from 8 to 51 feet and average about 30 feet below land surface.

\section{TERRACE DEPOSITS}

Segments of terraces at two levels are found along both sides of the Arkansas River. The upper surface of the low terrace ranges from 20 to 50 feet above the flood plain; the surface of the high terrace ranges from 60 to 120 feet above the flood plain. In this report the deposits beneath the low and high terraces are mapped and described as a single unit. Some of the larger areas of terrace deposits which contain significant amounts of ground water used for domestic and stock purposes are discussed below.

The city of Muskogee (pl. 1) is in part on a terrace segment that extends north and east of the city to the bank of the Arkansas River. Thicknesses of the deposits ranging from 22 to 33 feet were penetrated in four test and observation wells that were augered north and east of the city. Samples taken from three wells consisted mostly of silt and fine sand, but test-well $15 \mathrm{~N}-19 \mathrm{E}-33 \mathrm{bbb} 1$ penetrated about 4 feet of coarse sand and fine to medium gravel.

Six test and observation wells in the terrace segment north of Muskogee and north of the Arkansas River in the south part of T. 16 N., R. 18 E., penetrated deposits ranging from 27 to 82 feet in thickness. Samples taken from these wells were composed mostly of silt and very fine sand and small amounts of medium to coarse sand.

The terrace segment at Fort Gibson is about a mile wide and extends southeast for about $2 \frac{1}{2}$ miles. Information obtained from two test holes in these deposits indicates they are relatively thin and composed mainly of silt and very fine sand.

The terrace segment on which the town of Braggs is located covers an area of about 16 square miles and is one of the most extensive in the report area. The total thickness of the deposit is not known, but wells $13 \mathrm{~N}-20 \mathrm{E}-8$ baa 1 and $14 \mathrm{~N}-20 \mathrm{E}-31 \mathrm{ccc} 1$ were augered to a depth of 92 feet without reaching bedrock. The data from nine test and observation wells augered in this area indicate that the terrace deposit ranges in thickness from a thin mantle near the bedrock inliers west of Braggs to more than 92 feet in secs. 5,6 , 7, and 8 in T. $13 \mathrm{~N}$., R. 20 E. Samples taken from these wells ranged in size from silt to very coarse sand but were primarily medium sand.

The terrace segment north of the U.S. Highway 59 bridge across the Arkansas River covers an area of about 9 square miles. Five test and observation wells show that these deposits range from 5 to 57 feet in thickness. Samples taken from well $10 \mathrm{~N}-24 \mathrm{E}-5 \mathrm{bbc} 1$ were mostly medium to coarse sand but contained small amounts of fine to medium 
gravel from depths of 7 to 31 feet. Well $10 \mathrm{~N}-24 \mathrm{E}-4 \mathrm{ccc} 1$ penetrated mostly medium sand but contained smaller amounts of finer and coarser sand from depths of $\mathbf{3 7}$ to 57 feet. Samples taken from the remaining test and observation wells were composed mainly of silt and very fine sand.

Three areas of relatively large segments of terrace deposits where no test holes were augered includes parts of secs. 1, 2, 11, and 12, T. 11 N., R. 22 E., and secs. 9-15, T. 10 N., R. 25 E., Sequoyah County; and an area northeast of the town of Spiro in T. 9 N., R. 26 E., LeFlore County.

The depths to water measured in 32 wells in the terrace deposits range from 6 to 48 feet and average about 30 feet. The large variation is due to the location of the wells on topographically high or low ground.

Except for small isolated patches which contain no appreciable amount of ground water, the terrace deposits along the Arkansas River yield small to moderate amounts of water adequate for most domestic and stock use. Wells of large yield probably cannot be developed in the terrace deposits.

\section{AIIUVIUM}

Deposits of Recent alluvium underlying the flood plain consist of clay, silt, sand, and gravel in proportions that vary locally but remain reasonably consistent throughout the flood plain for broad areal correlation. Alluvium generally is gradational from clay or silt at the top to sand and gravel at the base. It ranges in thickness from a featheredge at its contact with the terrace or bedrock formations to a maximum of 55 feet, and averages about 40 feet.

By interpretation of aerial photographs and surface mapping, the alluvium was subdivided into several types of flood-plain deposits, such as point-bar, natural-levee, backswamp, and channel-fill deposits, (pl. 1) (Waterways Experiment Station, 1951). Point bars represent depasits formed by lateral accretion; natural levee, backswamp, and channel fill represent deposits formed by vertical accretion or overbank flow. Basically, point bars originate within the confines of the channel; natural-levee, backswamp, and channel-fill deposits consist of material deposited as a result of flood water flowing or standing outside the channel (Wolman and Leopold, 1957, p. 91).

Point-bar deposits are formed on the convex bank or inside stream meanders by lateral accretion, as the meander curve increases in radius and migrates downstream. Deposition is related to the circular flow - associated with the channel bend. Both the deposition on the convex bank and the simultaneous erosion on the concave bank tend to be 
greatest just downstream from the position of maximum curvature. The point-bar deposits at the surface consist mainly of fine to very fine sand and silt, which grades downward into coarser grained material; because of their mode of deposition, at any given place, the deposits may be extremely heterogeneous. In places the point bars are covered with a veneer of natural-levee deposits. These areas are mapped as point-bar deposits if the characteristic point-bar topography has not been completely obscured by the natural-levee material.

Natural levees are formed along the river banks during times of overbank flow. When the river overflows its banks, the sudden decrease in flow velocity causes a greater deposition of suspended load nearest the river. The coarser materials are deposited along the crest of the natural levees; the finer materials are carried farther into the adjacent backswamp. The crests of the natural levees are usually about 10 feet above the adjacent flood plain and slope gently landward and more steeply toward the stream channel. They are composed principally of fine sand and silt at the top and contain varying amounts of clay. Because the deposits are gradational and merge into the finer grained material of the adjacent flood plain, the mapped boundary of the levee away from the river bank is more or less arbitrary. The natural-levee deposits are areally extensive, although probably thicker along the concave banks of present and abandoned channel bends. Because natural levees are well drained and are underlain by sandy and silty material, they are well suited for agriculture.

Backswamps include the low areas of the flood plain away from the river and from natural levees. The deposits laid down in backswamps include the overbank sediments and consist principally of clay and minor amounts of silt and sand. These fine-grained deposits are typically dark to reddish brown. They range in thickness from 15 to 25 feet, and are underlain by coarser sand and gravel.

Channel-fill deposits are formed when river-meander loops are abandoned in places where the river shortens its course. These abandoned segments of meander loops eventually become filled with sediment and frequently border the convex sides of point-bar deposits. Where the angle of diversion of a new stream course is small, flow continues through the old river channel for a considerable period, and the upper arm of the cutoff-meander loop soon becomes filled with sand or silty material. Deposits in the lower, or downstream, arm of the cutoff-river channel are commonly finer grained than those in the upper arm. After complete isolation, most of the old channel is converted into a lake that is slowly filled with clay and silt from occasional floods, and it becomes farther removed as the river migrates 
away from the old channel. Central parts of filled channels are commonly called "clay plugs" because the deposits, composed largely of clay and silt, are relatively impermeable. Test holes in a filled channel southwest of Fort Smith (section $C-C^{\prime}$, pl. 1) show thickness of silt and clay to exceed 30 feet.

In places, alluvium of tributary streams draining into the Arkansas River flood plain forms the deposits described previously. Distinction of the various types is not made on an areal basis, and the deposits are mapped (pl. 1) as a single unit called "tributary alluvium." The tributary alluvium generally is composed of very fine grained sand, silt, and clay and has low permeability.

A general feature of the alluvium is the gradation in grain size from gravel, or coarse sand, near the base of the deposit to silt and clay near the surface. (See geologic sections pl.1.) Because alluvial material of one grain size grades complexly into that of another, the line separating the upper and lower material is only approximate. In places the thickness of the upper part may exceed 40 feet, but it is typically 20-30 feet. The lower part of the alluvium, composed of sand and gravel, is the most permeable and is typically 10-20 feet thick.

Alluvium underlying the flood plain is the principal aquifer along the Arkansas River. The general character, distribution, and thickness are shown on plate 1. Most of the alluvium has some coarse sand and gravel at its base, but large-capacity wells cannot be developed in some areas. These areas shown on the geologic map (pl. 1) as backswamp deposits, channel-fill deposits, or tributary alluvium generally have proportionately greater amounts of clay, silt, and fine sand and will not yield water readily to wells. Areas shown as point-bar deposits or natural-levee deposits generally have proportionately greater amounts of coarser materials which transmit water more readily and ordinarily yield moderate to large quantities of water.

Measured yields from four aquifer tests range from 130 to $860 \mathrm{gpm}$ (gallons per minute). Yields of irrigations wells reported by farmers range from 200 to $1,000 \mathrm{gpm}$. It is likely that yields ranging from 200 to $600 \mathrm{gpm}$ can be obtained in large areas of alluvial point-bar and natural-level deposits, and yields of 100 to $200 \mathrm{gpm}$ in most areas of backswamp deposits.

\section{GROUND WATER IN THE ALLUVIUM}

\section{PRINCIPLES OF OCCURRENCE}

Ground water in the alluvium is derived primarily from the infiltration of precipitation that falls as rain or snow. Part of the precipitation runs off directly into streams, a part evaporates, and a 
part is transpired by vegetation. The part that escapes surface runoff, evaporation, and transpiration percolates downward through the soils and alluvium into the zone of saturation.

Clay, silt, sand, and gravel of the alluvial deposits along the Arkansas River contain innumerable openings, called voids or interstices. These openings are the receptacles that contain ground water. The ratio of the volume of open spaces or voids to the total volume of the material is the porosity of the material and is expressed as a percentage. A material is said to be saturated when all its interstices are filled with water. Well-sorted deposits of uncemented gravel, sand, or silt have a high porosity, regardless of the size of the particles. Poorly sorted deposits have much lower porosities because the finer particles tend to fill or plug many of the interstices between the larger particles.

Porosity determines the amount of water that a material can hold, but the amount of water that a saturated material will yield when allowed to drain by gravity is less than the porosity of the material because some of the stored water is retained in the open spaces by capillarity. The specific yield of a water-bearing material is the ratio of the volume of water drained by gravity to the total volume of the material, and generally the ratio is stated as a percentage. Under water-table conditions the specific yield is approximately equal to the coefficient of storage. The coefficient of storage may be defined as the volume of water an aquifer releases or takes into storage per unit surface area per unit change in the component of head normal to that surface. Because drainage from the finer materials in the upper part of the alluvium is slow, the coefficients of storage computed from aquifer tests usually are smaller than the specific yield determined from laboratory analyses of samples in a particular area. However, these coefficients of storage are believed to represent the response of the aquifer to short-term changes in head, and they are useful in analyzing the effects of pumping for short periods and the short-term effect on ground-water levels caused by variations in the river stage. The specific yield determined in the laboratory is useful in analyzing changes in storage that result from permanent or long-term change in water levels.

The rate at which an aquifer transmits water depends upon the permeability of the aquifer. The coefficient of permeability is defined as the volume of flow per unit time per unit hydraulic gradient through a unit area. The coefficient of permeability in meinzer units may be expressed as the rate of flow of water in gallons per day through a cross-sectional area of. 1 square foot under a hydraulic gradient of 100 percent at a temperature of $60^{\circ} \mathrm{F}$. The field coeffi- 
cient of permeability is defined as the number of gallons of water a day that percolates under prevailing conditions through each mile of water-bearing material under investigation (measured at right angles to the direction of flow) for each foot of thickness of the material and for each foot per mile of hydraulic gradient (Wenzel, 1942, p. 7). Permeability is related not only to the number and size of openings in a material but also to the degree of interconnection of these openings. For example, clay or, silt may have relatively high porosity, but, because of the small size of the particles, the voids between the particles are very small, and the water in these voids is held by molecular attraction as a thin layer on the surface of each particle. These layers of water are not free to move in fine-textured material; therefore, the permeability, or water-transmitting capacity, of the material is low even though its porosity, or water-bearing capacity, is high. The coefficient of transmissibility is equal to the field coefficient of permeability multiplied by the thickness (in feet) of the saturated part of the aquifer.

\section{PHYSICAL AND HYDROLOGIC PROPERTIES}

The quantity of water that an aquifer (a water-bearing material or rock) will yield depends upon the physical and hydrologic properties of its constituent materials. Detailed descriptions of the logs of test and observation wells drilled in the alluvium are useful in appraising its hydrologic properties. However, more accurate quantitative estimates require comprehensive analyses of the water-bearing materials by laboratory and aquifer tests. Laboratory tests of samples collected during drilling were made to determine their physical and hydrologic properties. Aquifer tests were made at four locations to determine the hydrologic properties of the alluvium under field conditions. Hydrologic properties determined by laboratory methods included porosity, specific yield, and permeability; those determined by aquifer tests included permeability, transmissibility, and storage.

\section{LABORATORY TESTS}

The physical and hydrologic properties of the alluvial sediments were determined by analyses of samples in the U.S. Geological Survey Hydrologic Laboratory at Denver, Colo. Work in the laboratory included tests to determine the dry-unit weight, porosity, specific yield, and permeability coefficients of disturbed samples. The samples were also analyzed mechanically to determine size, distribution, and percentages of constituent grains. The results of laboratory determinations are summarized in table 2. 
TABLE 2.-Physical and hydrologic properties of the alluvium

\begin{tabular}{c|c|c|c|c}
\hline Well & $\begin{array}{c}\text { Depth } \\
\text { (feet) }\end{array}$ & $\begin{array}{c}\text { Porosity } \\
\text { (percent) }\end{array}$ & $\begin{array}{c}\text { Specific } \\
\text { yield } \\
\text { (percent) }\end{array}$ & $\begin{array}{c}\text { Coefficient } \\
\text { of permea- } \\
\text { bility (gpd } \\
\text { per sq ft) }\end{array}$ \\
\hline
\end{tabular}

LeFlore County

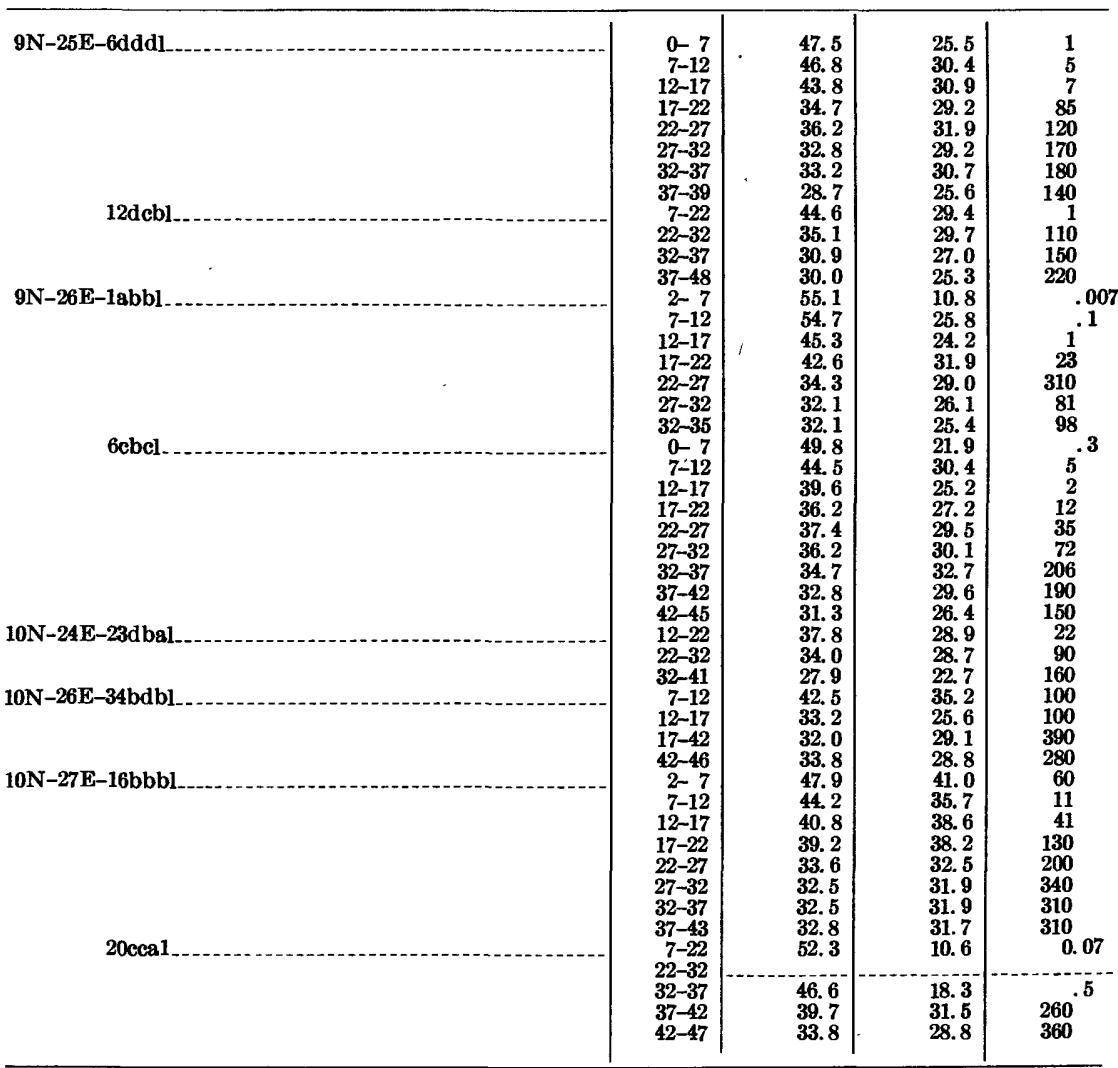

Sequoyah County

\begin{tabular}{|c|c|c|c|c|}
\hline $10 \mathrm{~N}-26 \mathrm{E}-22 \mathrm{bab} 1$ & $\begin{array}{r}0-7 \\
7-12 \\
12-15 \\
15-17 \\
17-22 \\
22-27 \\
27-32 \\
32-37 \\
37-42 \\
7-17 \\
17-32 \\
32-47 \\
7-12 \\
12-17 \\
17-22 \\
22-27 \\
27-32 \\
32-37 \\
37-42 \\
42-44\end{array}$ & $\begin{array}{l}47.2 \\
47.2 \\
43.4 \\
44.2 \\
39.6 \\
27.2 \\
31.3 \\
30.9 \\
32.5 \\
43.0 \\
42.9 \\
34.2 \\
50.9 \\
47.9 \\
47.2 \\
39.6 \\
41.9 \\
43.4 \\
43.8 \\
32.8\end{array}$ & $\begin{array}{l}28.2 \\
25.0 \\
32.4 \\
40.5 \\
36.4 \\
25.0 \\
30.1 \\
29.7 \\
26.2 \\
28.3 \\
34.1 \\
29.8 \\
13.8 \\
33.9 \\
37.7 \\
31.3 \\
32.3 \\
31.2 \\
34.1 \\
31.7\end{array}$ & \begin{tabular}{c}
0.6 \\
1 \\
4 \\
160 \\
56 \\
55 \\
200 \\
220 \\
300 \\
7 \\
31 \\
79 \\
\multicolumn{1}{c}{.02} \\
14 \\
10 \\
22 \\
8 \\
11 \\
430
\end{tabular} \\
\hline
\end{tabular}


TABLE 2.-Physical and hydrologic properties of the alluvium-Continued

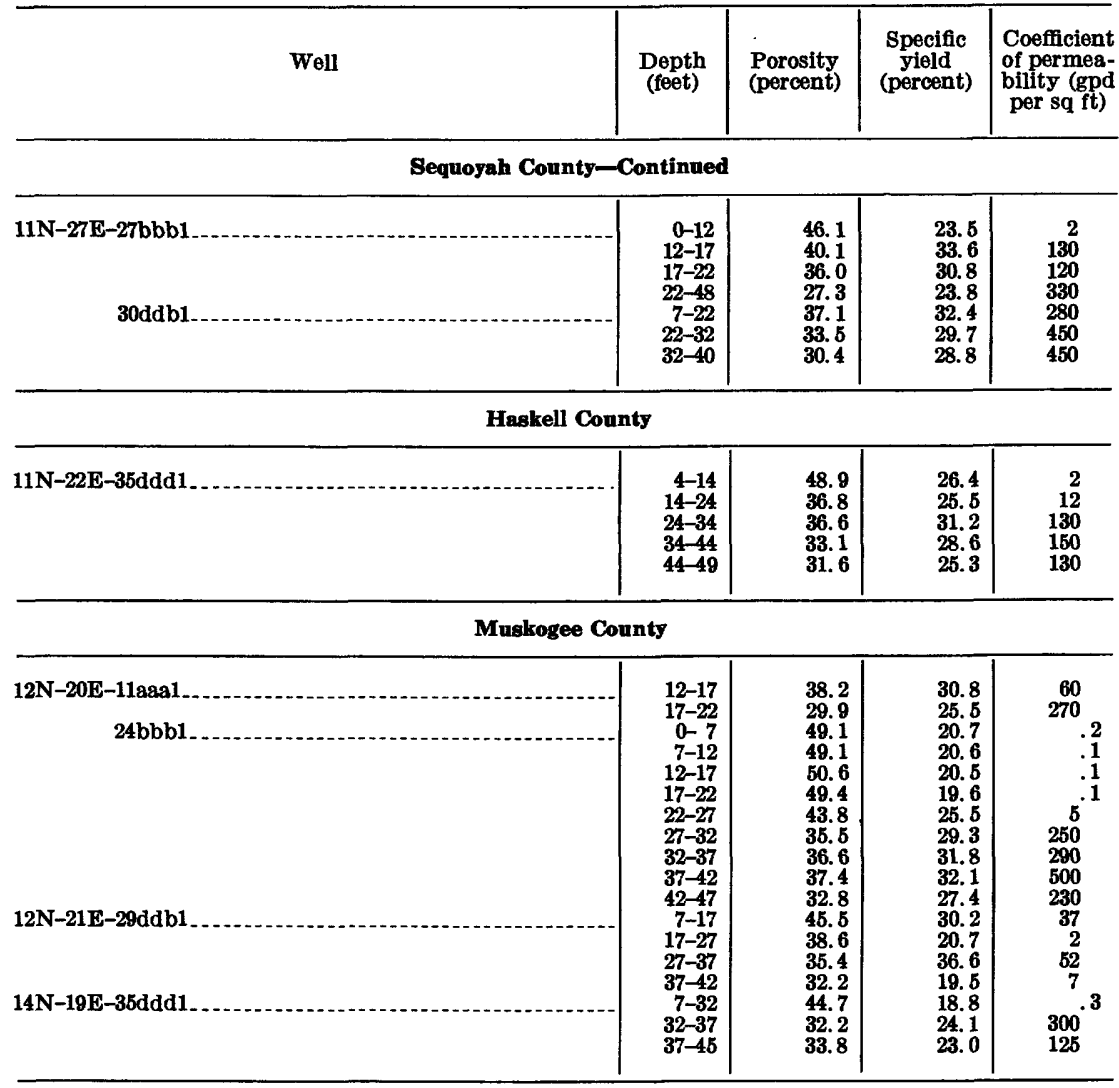

AQUIFER TESTS

The field method for determining the coefficients of permeability, transmissibility, and storage ordinarily consists of pumping a well steadily at a known rate of discharge and measuring the drawdown of water levels during pumping and the recovery of water levels after pumping stops. Measurements are made in the pumped well and one or more observation wells. These methods are described by Wenzel (1942) and, more recently, by Ferris and others (1962).

Four aquifer tests were made in the alluvium during this investigation. During each test, with one exception, a well was pumped at a constant rate for 72 hours and the drawdown of the water level in the pumped well and its two or more observation wells was measured. After pumping was stopped, the recovery of the water was measured for 72 hours. The exception was pumped well $11 \mathrm{~N}-27 \mathrm{E}-30 \mathrm{dac} 1$, where measurements of water level could not be made; the pumping 
rate of this well varied considerably during the drawdown phase of the test, and only the rate of water-level recovery in two observation wells was analyzed.

The drawdown and recovery data obtained from the aquifer tests were analyzed by means of the Theis nonequilibrium formula, the modified nonequilibrium formula, and the Theis recovery formula (Ferris and others, 1962, p. 92-102).

Table 3 summarizes the results obtained from six aquifer tests. Included in the table are results of two aquifer tests conducted by the U.S. Geological Survey in 1948 (Schoff and Reed, 1951, p. 27) on wells in the alluvium about 3 miles southwest of Fort Gibson, Okla.

\section{RELATION OF LABORATORY AND FTELD DATA}

Permeability values obtained from laboratory analyses (table 2) are much lower than permeability values computed from aquifer tests (table 3) in the same general area. The discrepancy is caused by the difficulty of bringing material having a high permeability to the surface by drill, especially medium to coarse gravel. Thus, these samples did not represent the character of the material in place, and the permeabilities differed considerably from that determined on undisturbed material by aquifer tests.

To estimate the hydrologic properties for a large area, the aquifer properties must be known at many different points. Because it was not feasible to conduct sufficient aquifer tests to define in detail the hydrologic characteristics of the alluvium between Muskogee and Fort Smith, the aquifer tests were supplemented by laboratory tests and by careful examinations and interpretations of test- and observation-well cuttings to extrapolate known data to other parts of the area.

To determine the relation of grain size to permeability for materials in the alluvium, laboratory data were used to graph (on logarithmic

TABLE 3.-Summary of the coefficients of transmissibility, permeability, and storage determined by aquifer tests

\begin{tabular}{|c|c|c|c|}
\hline Well & $\begin{array}{c}\text { Coefficient } \\
\text { of trans- } \\
\text { missibility } \\
\text { (gpd } \\
\text { per ft) }\end{array}$ & $\begin{array}{c}\text { Coefficient } \\
\text { of permea- } \\
\text { bility } \\
\text { (gpd per } \\
\text { sq ft) }\end{array}$ & $\begin{array}{l}\text { Coefficient } \\
\text { of storage }\end{array}$ \\
\hline $\begin{array}{l}\text { LeFlore County: } \\
9 \mathrm{~N}-25 \mathrm{E}-12 \mathrm{dcbl}\end{array}$ & 85,000 & 2,500 & 0.05 \\
\hline $\begin{array}{l}\text { Sequoyah County: } \\
\text { 11N-27E-30ddbl.- }\end{array}$ & 109,000 & 3,600 & .20 \\
\hline $\begin{array}{l}\text { Muskogee County: } \\
12 N-21 \mathrm{E}-29 \mathrm{ddd} 1 \\
14 \mathrm{~N}-19 \mathrm{E}-35 \mathrm{ddd1} \\
15 \mathrm{~N}-19 \mathrm{E}-2 \text { dedl }\end{array}$ & $\begin{array}{l}50,000 \\
83,000 \\
67,000\end{array}$ & $\begin{array}{l}2,500 \\
4,100 \\
3000\end{array}$ & $\begin{array}{l}.03 \\
.004\end{array}$ \\
\hline $23 \mathrm{bddl} i_{-}$ & 79,000 & 2,800 & \\
\hline
\end{tabular}

1 Schoff and Reed (1951). 
paper) median grain size of samples against permeability (fig. 4). The point scatter shown on the graph is believed to be due to differences in sorting, character, and arrangement of grains, although the pattern shows a definite relation between sand sizes and permeability. This relation may be expressed as:

$$
K=C d^{2}
$$

where the permeability, $K$, is directly proportional to some constant, $C$, and the square of the median grain size, $d$ (Jacob, 1950, p. 324).

This relation between grain size and permeability was used to revise the permeabilities of well-log samples at sites where aquifer tests had been made to a range of values that would conform to permeabilities obtained in the laboratory and in the aquifer tests. These values are given in table 4.

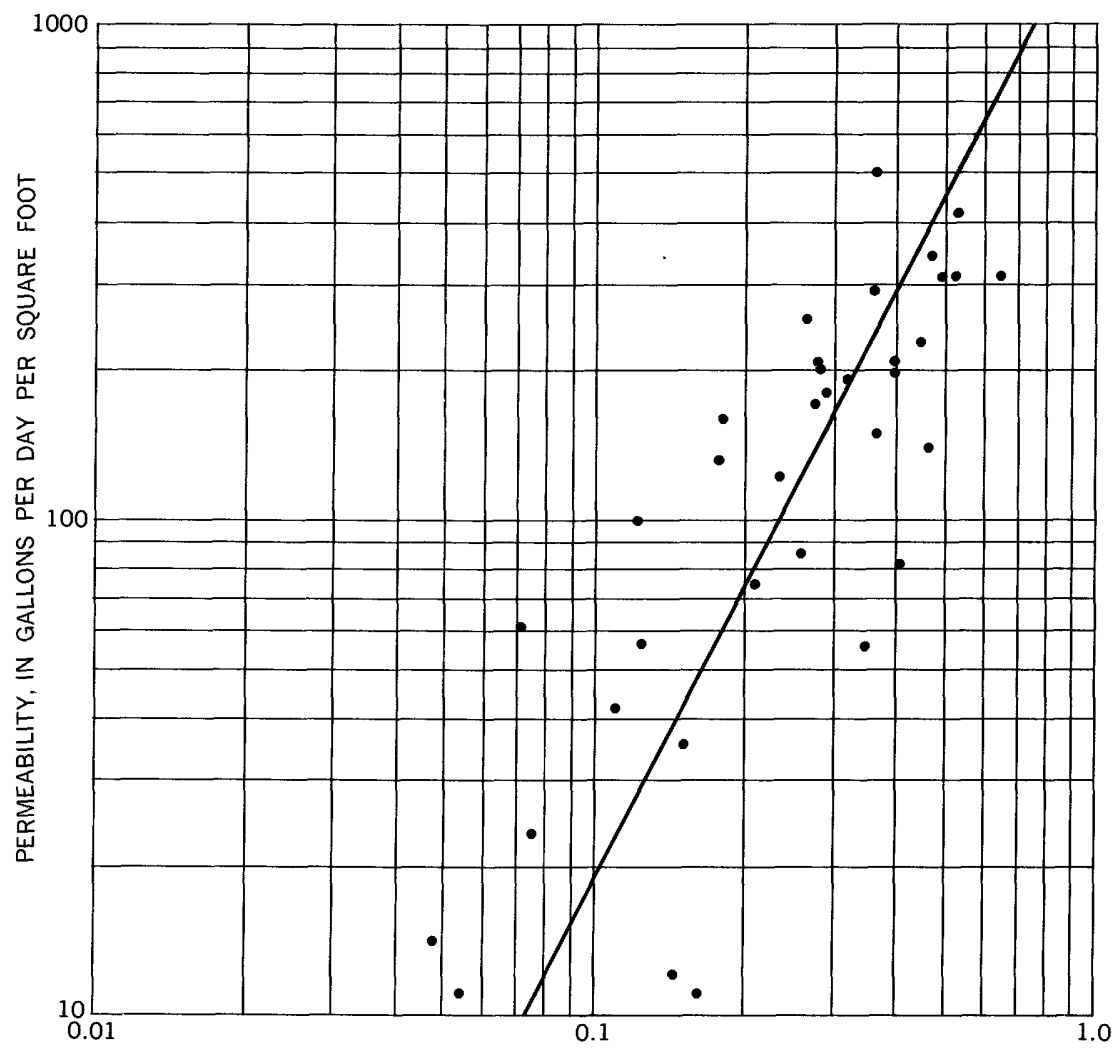

MEDIAN GRAIN SIZE, IN MILLIMETERS

Frgure 4.-Relation of median grain size to permeability of samples from Muskogee, Okla., to Fort Smith, Ark. 
TABLE 4.-Permeabilities of the alluvium of the Arkansas River Valley

\begin{tabular}{|c|c|}
\hline $\begin{array}{c}\text { Type of material } \\
\text { (sand) }\end{array}$ & $\begin{array}{l}\text { Field coefficient of } \\
\text { permeability } \\
\text { gpd per sq ft) }\end{array}$ \\
\hline Very coarse, and very fine gravel & $6,000-15,000$ \\
\hline Very coarse & $3,000-9,000$ \\
\hline Coarse and very coarse & $1,500-4,000$ \\
\hline Coarse & $800-2,000$ \\
\hline Medium and coarse & $400-1,000$ \\
\hline Medium & $200-500$ \\
\hline Fine and medium... & $100-$ \\
\hline Fine & $50-$ \\
\hline Very fine and fine. & 20- \\
\hline Very fine........ & $10-$ \\
\hline
\end{tabular}

FLUCTUATIONS OF THE PIEZOMETRIC SURFACE

The piezometric surface is defined as the surface represented by the water levels in wells tapping any single aquifer whether artesian, water table, or both. This surface is not level but has irregularities that correspond roughly to the topography. Irregularities in the piezometric surface also are due to local differences in the rate of recharge and discharge, permeability, and thickness of the formation. In this report the average piezometric surface (pl. 2) is based on the average of 10-14 measurements of water levels in each well made at regular intervals during the 5-year period 1958-62.

Water-level fluctuations, except those caused by atmosphericpressure changes, are due to changes in the rate of recharge to and discharge from the aquifer and to the river stage. Water levels in wells will rise or decline according to whether recharge is greater or less than discharge. In the report area, recharge is by precipitation directly on the alluvial surface, and discharge mainly by evapotranspiration and seepage by underflow into the river. Seasonal variations in the rate and magnitude of recharge to and discharge from the aquifer result in seasonal water-level fluctuations that range from 2 to 4 feet. The following generalization of seasonal water-level fluctuation during 1958-62 is based on hydrographs of 50 wells in the alluvium. Water levels are highest in the early spring and lower in late spring or early summer, principally because water loss resulting from evapotranspiration is greater. The levels continue to decline during the summer, and the decline is accelerated locally by pumping for irrigation. Water levels begin to rise in late autumn, after irrigation stops and water loss from evapotranspiration decreases, and continue to rise during the winter; they reach their highest levels again in early spring.

Fluctuations in the stage of the Arkansas River have a major influence on water-level fluctuations near the river. This influence diminishes with distance from the river, as illustrated in figure 5 which 


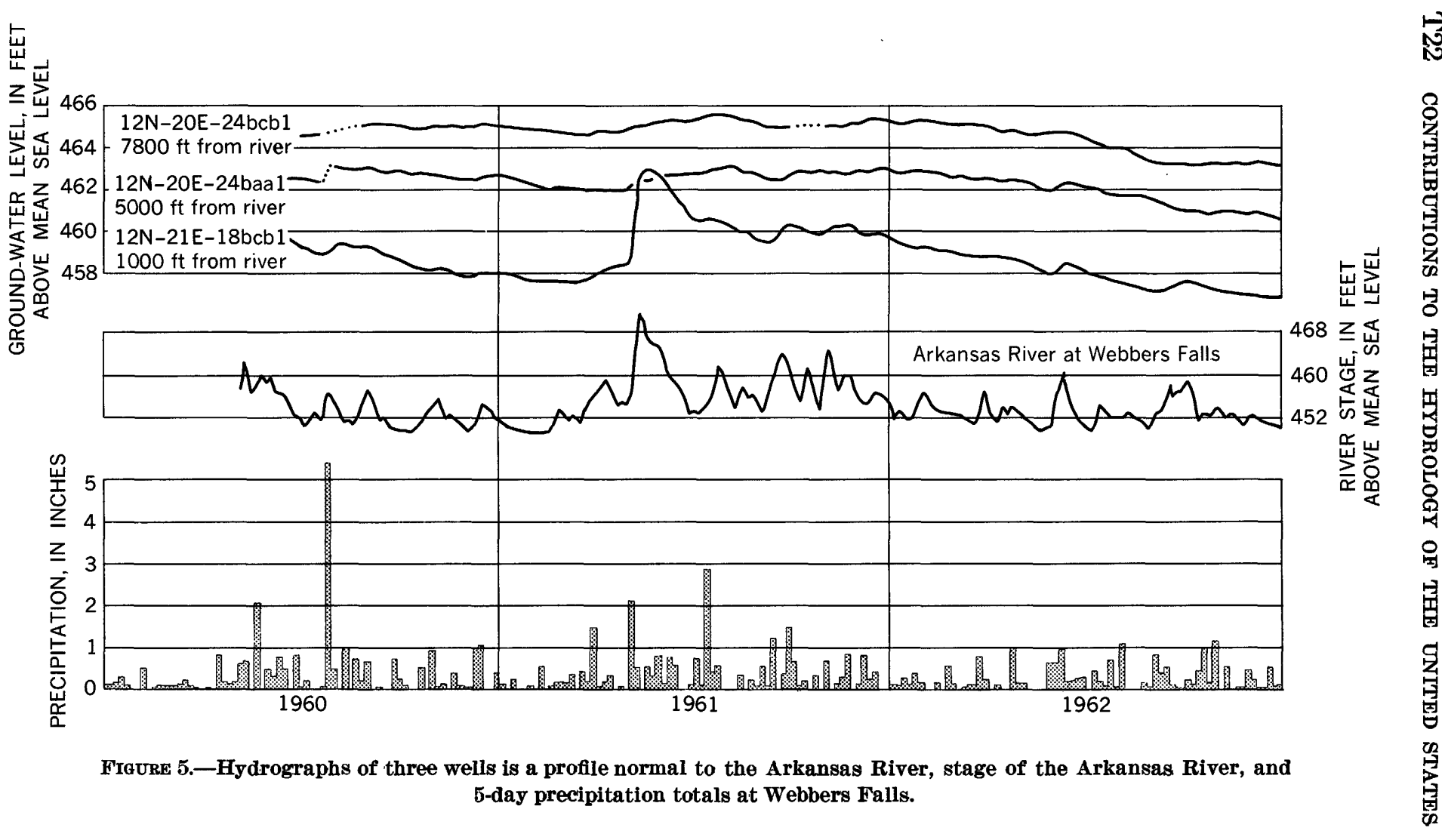


shows hydrographs of three wells in a profile normal to the Arkansas River near Webbers Falls. Well 12N-21E-18bcb1 is 1,000 feet from the river, $12 \mathrm{~N}-20 \mathrm{E}-24$ baa1 is 5,000 feet from it, and $12 \mathrm{~N}-20 \mathrm{E}-24 \mathrm{bcb} 1$ is 7,800 feet. The water level in the well near the river responds quickly to fluctuations in river stage. The two distant wells along the profile reflect fluctuations that compare more closely to local precipitation than to the stage of the river.

The diminishing effect of the river stage on water-level fluctuations with distance from the river is further illustrated by plotting the magnitude of the fluctuations of several wells at varying distances from the river during a period of exceptionally high flow in May 1961 (fig. 6). The distances from the river are shown on the abscissa and the height of water-level fluctuations in wells is shown on the ordinate. The curve indicates the rapid decrease in the influence of the river on water-level fluctuations as the distance from the river is increased. It shows that the influence of the river during this particular high stage did not extend much beyond 3,000 feet from the river.

\section{MOVEMENT}

Ground water moves down the hydraulic gradient from areas of recharge to areas of discharge. Plate 2 shows the configuration of the average piezometric surface of the ground-water body by contour lines that connect points of equal altitude on the average piezometric surface. The general direction of ground-water movement, which is at right angles to the contours, is toward the Arkansas River and its main tributaries with a component of movement downstream.

The hydraulic gradient in the alluvium ranges from 2 to 20 feet per mile, but over most of the area averages about 10 feet per mile. The gradient is much steeper in areas of lower permeabilities, such as near the confluence of the Verdigris and the Arkansas Rivers northeast of Muskogee and along the Poteau River south of Fort Smith. The hydraulic gradient in the terrace deposit averages about 60 feet per mile north of Muskogee and near Braggs. Ground water moves toward and enters the alluvium, which is hydraulically connected to and topographically lower than the terrace deposit.

\section{RECHARGE}

Ground-water recharge is the addition of water to a ground-water reservoir. It may be accomplished by underflow from adjacent areas and aquifers, infiltration of excessive irrigation water, influent seepage from streams and ponds, and infiltration of precipitation. Infiltration of precipitation is the most important source of recharge in the Arkansas River valley. 
CONTRIBUTIONS TO THE HYDROLOGY OF THE UNITED STATES

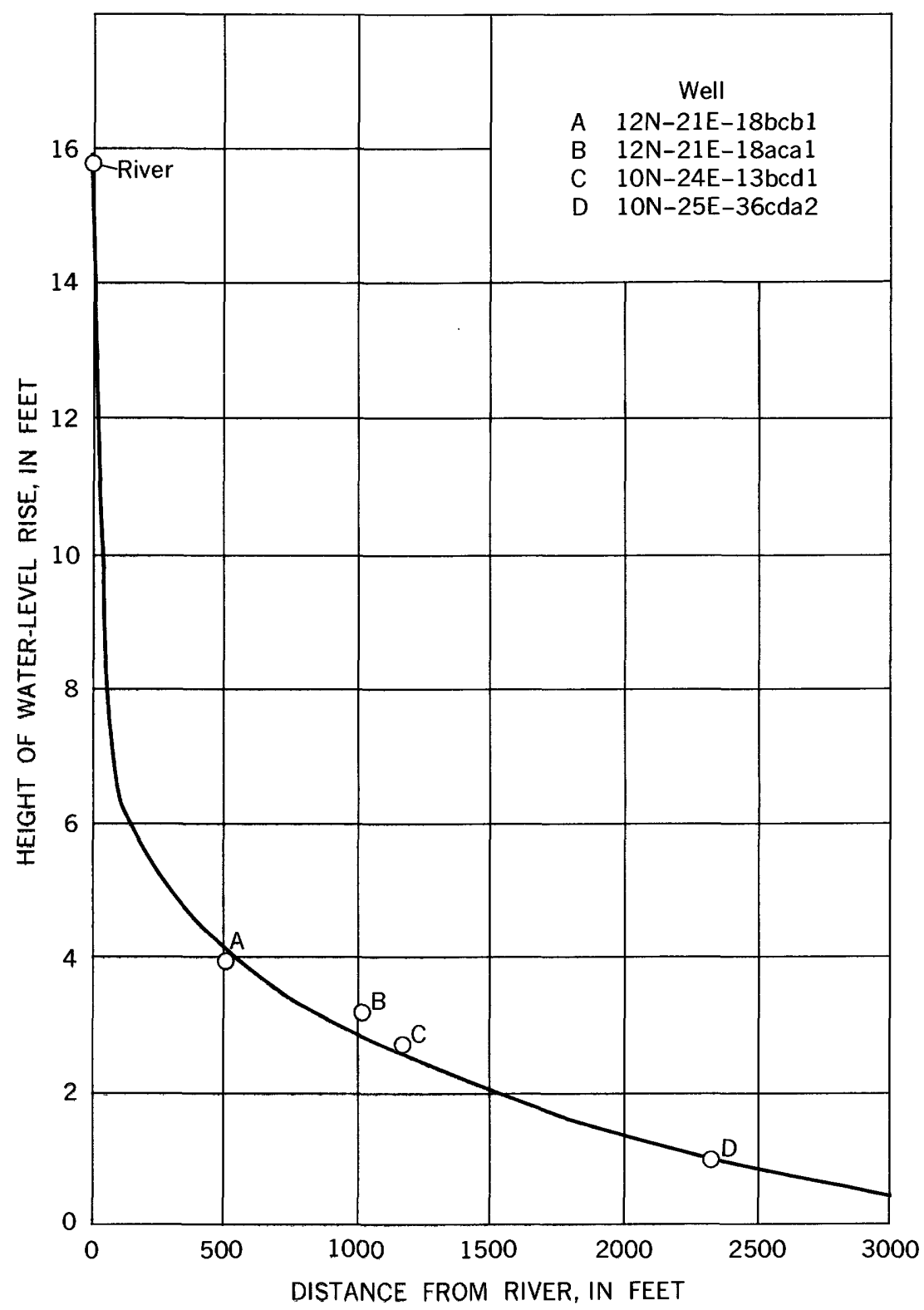

FIgure 6.-Height of water-level rises at distances from the river.

Average annual precipitation is about 43 inches, but only a part of this water reaches the saturated zone. The greatest part is lost through evapotranspiration and surface runoff, but a small part goes to ground-water recharge. Recharge is greatest in areas underlain 
by more permeable surface materials, such as point-bar and naturallevee deposits (pl. 1). The amount of recharge varies with the amount and distribution of precipitation and the amount of water lost by evapotranspiration. Recharge usually is effective during late fall through early spring, when the amount of precipitation lost by evapotranspiration is low.

The piezometric surface in alluvium is affected by several hydrologic agents: a hydraulically connected stream that varies continually in head, recharge from precipitation, discharge by evapotranspiration, and pumping from wells. Because of the dynamic and interrelated action of these agents, the aquifer never achieves a stage of precise equilibrium, although under natural conditions the hydrologic system of the aquifer is in approximate equilibrium. The average piezometric surface will be in approximate equilibrium with the average stream stage, and the amount of recharge will equal the amount of discharge when recharge and discharge are normal over a long period of time.

The rate of recharge by infiltration of rainfall is computed at several places in the project area by analysis of the average piezometric-surface map (pl. 2). A part of the aquifer isolated by natural hydrologic boundaries was selected, and measurement of the flow of ground water into or out of the isolated area allowed the computation of recharge to or discharge from the area. Ground-water flow was indirectly measured on the basis of the average hydraulic gradient and transmissibility of the aquifer, and computed by a modification of Darcy's law, which is expressed as

$$
Q=T I L
$$

where $Q$ is the flow in gallons per day, $T$ is the transmissibility of the aquifer in gallons per day per foot, $I$ is the average hydraulic gradient in feet per mile, and $L$ is the length of the line, in miles, across which the flow is being computed.

Approximate rates of recharge and discharge are tabulated in table 5 for about half the total area of alluvium. Average recharge, in inches per year, is computed from average discharge figures because, as previously stated, recharge and discharge are equal when the aquifer is in a state of equilibrium. On the basis of data in table 5, it was estimated that the average annual recharge in the Arkansas River alluvium was equivalent to about 20 percent of the precipitation for the period of record. Recharge varies from 8 to 12 inches and is greatest in areas underlain by permeable point-bar and naturallevee deposits, and least in areas underlain by backswamp and channelfill deposits. Recharge to 140 square miles of alluvium between Mus- 
TABLE 5.-Recharge and discharge in selected areas of the Arkansas River valley

\begin{tabular}{|c|c|c|c|c|c|c|}
\hline Area & $\begin{array}{c}\text { Approxi- } \\
\text { mate size } \\
\text { (sq mi) }\end{array}$ & $\begin{array}{c}\text { Estimated } \\
\text { average } \\
\text { transmis- } \\
\text { sibility } \\
\text { (gpd per ft) }\end{array}$ & $\begin{array}{c}\text { Average } \\
\text { slope } \\
\text { (ft per mi) }\end{array}$ & $\begin{array}{l}\text { Approxi- } \\
\text { mate } \\
\text { length of } \\
\text { aquifer } \\
\text { (miles) }\end{array}$ & $\begin{array}{c}\text { Average } \\
\text { daily } \\
\text { discharge } \\
\text { (mgd) }\end{array}$ & $\begin{array}{c}\text { A verage } \\
\text { recharge } \\
\text { (in. per yr) }\end{array}$ \\
\hline 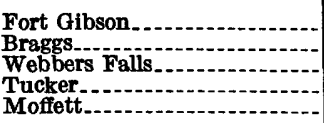 & $\begin{array}{r}10 \\
8 \\
13 \\
17 \\
24\end{array}$ & $\begin{array}{l}70,000 \\
50,000 \\
50,000 \\
50,000 \\
60,000\end{array}$ & $\begin{array}{r}10 \\
8 \\
8 \\
12 \\
10\end{array}$ & $\begin{array}{r}8 \\
11 \\
13 \\
12 \\
17\end{array}$ & $\begin{array}{r}5.6 \\
4.4 \\
5.2 \\
7.2 \\
10.2\end{array}$ & $\begin{array}{r}12 \\
11 \\
8 \\
9 \\
9\end{array}$ \\
\hline
\end{tabular}

kogee and Fort Smith was estimated, on the basis of an average recharge rate of 9 inches per year, to be about $60 \mathrm{mgd}$ (million gallons per day).

The amount of underflow from adjacent terrace deposits and from bedrock is probably small because the permeabilities of those rocks are low. Information derived from 29 test and observation wells augered in terrace deposits indicate that most deposits in the report area consist of varying amounts of clay, silt, and very fine sand. Terrace deposits that are relatively thick and extend over large areas may contribute water in significant amounts to the alluvium. These deposits are near Braggs in T. 13 N., R. 20 E.; near Muskogee in T. 16 N., R. 18 E., in T. 10 N., R. 24 E., and in T. 11 N., R. 22 E.; and northeast of Spiro in T. 9 N., R. 26 E. No tests were made in bedrock units to determine their hydrologic properties, but their permeabilities are believed to be small compared with the permeability of the alluvium, and consequently any exchange of water between alluvium and bedrock probably will be small and will occur along fractures and fissures in the bedrock.

Recharge resulting from infiltration of excessive irrigation water is not important because irrigation is limited at the time of writing (1963). Future development of irrigation in more favorable floodplain areas may cause irrigation practices to become an important factor in recharge to the alluvium.

Recharge by influent seepage occurs only for relatively short periods of time and short distances from the river during periods of extreme high stages of the river. Normally, the ground-water gradient is toward the river. As the stage of the river rises, the natural groundwater gradient toward the river is decreased and ground-water discharge into the river is reduced. As the river continues to rise, the ground-water gradient near the river is reversed temporarily and water from the river recharges the alluvium. When the stage of the river declines, the ground-water gradient near the river is again reversed; water stored in the alluvium near the channel returns to the river and restores the normal water-table gradient. The amount of 
recharge to the alluvium and the lateral distance that water levels are affected depend on the magnitude and duration of the rise in river stage.

\section{DISCHARGE}

When water derived from precipitation reaches the saturated zone, it becomes part of the ground-water body and moves in a direction determined by the hydraulic gradient to points of discharge. Ground water is discharged continuously from alluvium and terrace deposits by evapotranspiration, springs, wells, and seepage into streams.

Seepage into streams and evapotranspiration are the most important means of ground-water discharge. The rate at which ground water is discharged is influenced by the hydrologic properties of the aquifer, depth to water, slope of the piezometric surface, types and density of vegetation, and season of the year.

The general direction of movement of ground water in the alluvium is toward streams. The part that is not discharged by evapotranspiration, springs, and wells is discharged into streams by seepage. The total ground-water discharge into streams is not known, but the average discharge from selected areas was computed from the average piezometric surface map (table 5).

Evapotranspiration is the loss of water to the atmosphere by evaporation from land and water surfaces and by transpiration from plants. Ground water is discharged by evaporation in places where the water table or capillary zone is near the land surface. The degree that water will rise due to capillarity depends primarily upon the grain size of the material above the water table - the finer grained the material, the greater the distance the water will rise. The thickness of the capillary zone will vary from a few inches in sand to several feet in silt and light clay. The depths to which plant roots reach for water varies greatly with the different plant species, the different soils, the depth to water, and the amount of precipitation. Ordinary grasses and field crops, except alfalfa, do not draw water from depths of more than a few feet. Alfalfa, a phreatophyte, sends its roots into the capillary zone to depths greater than 10 feet under certain conditions. In most places the natural vegetation occurs along streams and abandoned channelways. Common types of vegetation that use large quantities of ground water include cottonwood, willow, and saltcedar, which send their roots to the saturated zone and intercept ground water that otherwise would be discharged into streams. Evapotranspiration of ground water is greatest where depths to water are least. In most parts of the flood plain the depth to water is about 15 feet, and discharge of ground water by evapotranspiration 
is probably small. Most of the precipitation that falls within the area is discharged by evapotranspiration before it reaches the saturated zone. It was estimated that about 20 percent of the precipitation penetrates to the saturated zone. Much of the remainder is discharged by evapotranspiration at or near the surface and by surface runoff into streams.

Most springs in the report area discharge at or near the base of high-terrace deposits. Yields from springs are probably small and are not an important source of ground-water discharge. A spring near Spiro, reported to be perennial, supplies drinking water for residents in that area, and its discharge is estimated to be about $3 \mathrm{gpm}$.

Water discharged by wells is used principally for irrigation, and in lesser amounts for domestic, public-supply, and industrial needs; these uses are listed in the order of the quantities pumped in 1962. The quantity pumped for each use is discussed in the section on "Utilization."

\section{STORAGE}

The storage capacity of alluvium along the Arkansas River valley depends upon the volume of saturated material and its specific yield. Alluvium between Muskogee and Fort Smith covers about 90,000 acres and the saturated material has an average thickness of about 25 feet. On the basis of the above dimensions and an assumed specific yield of 20 percent for the material, the average usable ground-water storage capacity is about 450,000 acre-feet.

\section{UTILIZATION}

In 1962 about 1,700 acre-feet of water was pumped from the alluvium. About 90 percent was used for irrigation, 5 percent for industry and public supply, and 5 percent for domestic and stock use.

\section{IRRIGATION SUPPLIES}

Use of ground water for irrigation is small except in the Webbers Falls area, where 17 irrigation wells were inventoried. Total annual pumpage for irrigation varies from year to year, depending upon the amount and distribution of rainfall during the growing season. According to a survey of irrigation in Oklahoma in 1963 (Duffin, 1963, p. 3-5), the irrigated acreage in Muskogee, Sequoyah, Haskell, and LeFlore Counties, all of which are in the alluvium of the Arkansas River, totaled 1,180 acres. On this basis, the annual pumpage is estimated to be about 1,500 acre-feet. Pumpage for irrigation at the 
present rate has very little effect upon the total volume of water stored in the alluvium.

Prior to 1959, surface centrifugal pumps were used as the most common method of lift. The centrifugal pump is connected by a manifold to three or more sandpoint wells, commonly 2 inches in diameter, which are driven about 10 feet apart in the alluvium. To lift water the pump must be within 20 feet of the pumping level of the water. The closer the pump is to the water level the more efficiently the pump will operate; therefore, many installations are below land surface in dug pits. Capacity of an installation of this type is estimated to be $200-500 \mathrm{gpm}$, depending on the size of the pump, number and diameter of wells, and permeability of alluvium penetrated by wells.

The increased installation of turbine pumps since 1959 indicates a growing preference by irrigators for the turbine over the centrifugal pump. Large-diameter wells used for irrigation are drilled by hydraulic-rotary or cable-tool methods, and most wells have 10- or 12-inch steel casings set on bedrock. Below the water table, wells have slotted casings or well screens and are completed with a 4- or 6-inch gravel-pack envelope. Discharge from a turbine-pump installation averages about $400 \mathrm{gpm}$ for wells which were inventoried, although dicharge of individual wells varies considerably according to the size of pump, number of stages, size of screen and gravel pack, well development, and properties of alluvium penetrated by a wall. A properly constructed and developed well equipped with a large turbine pump, at a favorable location in alluvium, should pump about $600 \mathrm{gpm}$.

\section{INDUSTRIAL AND PUBLIC SUPPLIES}

The only known industrial well is owned by the Oklahoma Gas and Electric Co. The well (15N-19E-21bddl), which is in the alluvium of the Arkansas River east of Muskogee, pumped an average of 48,000 gpd (gallons per day) in 1962.

The only public-supply well (14N-20E-31daal) in the report area furnishes water to the town of Braggs. It is located about $1 \frac{1}{2}$ miles southwest of Braggs on a high-terrace deposit. The well is 47 feet deep, has an 18-inch-diameter tile casing, and was dug at the site of a former spring. The spring fills three underground storage tanks nearby, and this water is pumped into a 30,000-gallon elevated storage estimated to be about 1,500 acre-feet. Pumage for irrigation at the 
average of $30,000 \mathrm{gpd}$. Webbers Falls and Moffett do not have publicsupply systems but obtain their water supplies from individual smalldiameter wells driven in the alluvium. Fort Gibson and Gore obtain their water supplies from the Neosho and Illinois Rivers.

\section{DOMESTIC AND STOCK SUPPUTES}

Domestic and stock wells in the alluvial deposits along the Arkansas River are drilled or driven. Drilled wells are commonly cased with 6-inch galvanized steel, which is perforated below the water table. Generally the driven wells are constructed with 2-inch pipe and a drive point fitted with a sand screen that is driven 10-15 feet below the water table. Most domestic and stock wells are equipped with cylinder pumps. The cylinder is below land surface and lifts the water to the point of discharge by suction. A few domestic wells are equipped with jet pumps that lift water by a stream of water under pressure. Pumping is concentrated in and around Moffett and Webbers Falls, and in the rural areas surrounding Gore, Braggs, and Fort Gibson. An estimate of the population and the density of farm dwellings in the project area indicates that probably less than 100 acre-feet per year is pumped from the alluvium and terrace deposits for domestic and livestock purposes.

\section{AREAS POTENTIALLY FAVORABLE FOR DEVELOPMENT OF GROUND WATER}

Quantities of ground water adequate for domestic or stock use are available almost everywhere on the alluvial flood plain. Larger quantities of water for irrigation, municipal, or industrial use are available in areas underlain by moderate thicknesses of permeable material. The permeable material is the principal water-bearing part of the aquifer and, as used in this report, is medium sand or coarser material. It is commonly 10-20 feet thick but may be as much as 40 feet thick. In most places the permeable material is predominantly medium to very coarse sand and gravel containing some finer sand, silt, or clay. However, where there is a high proportion of silt or clay mixed with the permeable material, the availability of water is reduced. The availability of water is increased if the permeable material is predominantly gravel or if the proportion of silt or clay is low. Comparison of well yields and thicknesses of permeable material at several pumping-test and irrigation-well sites indicate that where the thickness of the permeable material is greater than 15 feet, wells capable of yielding $200-600 \mathrm{gpm}$ can be developed. 
The thickness of the alluvium and the permeable material at each test-hole site is shown on plate 3. Areas where the thickness of the permeable material is estimated to be 15 feet or more are shaded; however, the size and shape of the shaded areas are only approximate, owing to the heterogeneous character of the alluvium and to the lack of detailed geologic data in most of the area.

\section{CHEMICAL QUALITY OF THE WATER}

By JoHN J. MURPHY

The suitability of water for beneficial use is dependent on its quality. Concentrations of calcium, sodium, sulfate, chloride, nitrate, fluoride, and dissolved solids, and hardness are some of the important characteristics of water that affect its use. This section discusses the quality of water in the alluvium, the suitability of the water for beneficial use, and the possible reasons for areal variations in water quality.

The significant factors that affect the quality of water in alluvium are the permeability and chemical composition of the surface and near-surface materials through which precipitation percolates, the chemical composition of the aquifer, seepage from adjacent or underlying formations, and the length of time the water is in contact with aquifer materials.

Because factors which affect water quality may act with varying intensities in different parts of the alluvium, samples were collected initially from more than 100 wells and test holes. To determine the variation in quality with time, wells selected from the initial group were sampled twice annually during 1960 and 1961 .

Water from most wells in the alluvium is of the calcium, magnesium bicarbonate type, hard, and of moderate dissolved-solids content (table 6). Except at a few places, sulfate, chloride, and nitrate concentrations are low. Scattered data indicate that concentrations of fluoride are about $0.2 \mathrm{ppm}$ (part per million) and that boron is generally less than $0.2 \mathrm{ppm}$.

The maximum, minimum, and modal concentrations of principal constituents determined.are shown in table 7. The modal, representing the concentration that occurs most often, is shown as a single value; different levels of dissolved-solids content occur so frequently that the central tendency of concentrations is a range rather than a single value. The specific conductance, an approximation of the dissolved-solids content, ranges from 160 to 2,870 micromhos and the modal conductance is 500 micromhos (table 7). The central tend ency, however, ranges from 250 to 750 micromhos. 
TABLE 6.-Chemical analyses of water from the alluvium along the Arkansas River between Muskogee, Okla., and Fort Smith, Ark.

\begin{tabular}{|c|c|c|c|c|c|c|c|c|c|c|c|c|c|c|c|c|c|c|c|c|c|c|}
\hline \multirow[b]{2}{*}{ Well } & \multirow[b]{2}{*}{$\left|\begin{array}{l}\text { Depth } \\
\text { of well } \\
\text { (feet) }\end{array}\right|$} & \multirow[b]{2}{*}{$\begin{array}{c}\text { Date of } \\
\text { collection } \\
\text { of sample }\end{array}$} & \multirow[b]{2}{*}{ 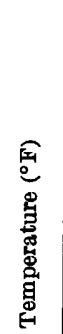 } & \multicolumn{12}{|c|}{ Constituents (ppm) } & \multicolumn{2}{|c|}{$\underset{\substack{\text { Hardness as as } \\
(\mathrm{ppm})}}{\mathrm{CaCO}}$} & \multirow[b]{2}{*}{ 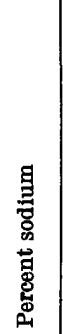 } & \multirow[b]{2}{*}{ 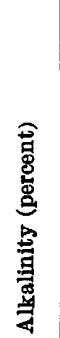 } & \multirow{2}{*}{ 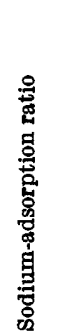 } & \multirow[b]{2}{*}{ 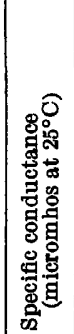 } & \multirow[b]{2}{*}{ pH } \\
\hline & & & & 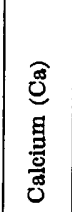 & 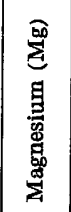 & 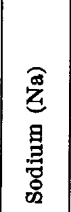 & 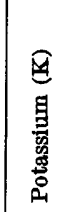 & 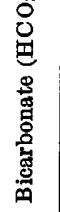 & 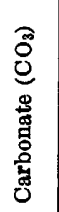 & 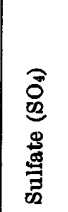 & 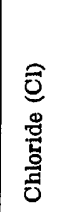 & $\begin{array}{l}\text { 国 } \\
\text { 苋 } \\
\text { 墨 }\end{array}$ & 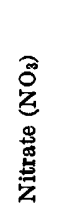 & $\begin{array}{l}\widehat{\oplus} \\
\text { : } \\
\text { क्षे }\end{array}$ & 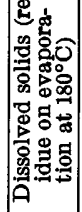 & 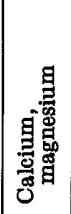 & 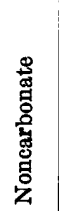 & & & & & \\
\hline 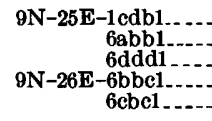 & $\begin{array}{l}\mathbf{4 2} \\
32 \\
31 \\
32 \\
21\end{array}$ & 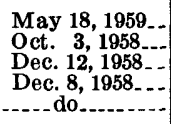 & $\begin{array}{l}64 \\
62 \\
63 \\
64 \\
66\end{array}$ & $\begin{array}{r}106 \\
98 \\
83 \\
61 \\
51\end{array}$ & \begin{tabular}{l|}
29 \\
1.3 \\
12 \\
17 \\
30
\end{tabular} & $\begin{array}{l}21 \\
14 \\
11 \\
18\end{array}$ & $\begin{array}{l}0.7 \\
.8 \\
1.0 \\
1.3\end{array}$ & $\begin{array}{l}458 \\
240 \\
334 \\
268 \\
288\end{array}$ & $\begin{array}{l}\mathbf{0} \\
0 \\
\mathbf{0} \\
\mathbf{0} \\
\mathbf{0}\end{array}$ & \begin{tabular}{|l}
15 \\
35 \\
4.1 \\
14 \\
30
\end{tabular} & $\begin{array}{l}14 \\
40 \\
11 \\
13 \\
17\end{array}$ & & $\begin{array}{r}0.0 \\
.1 \\
.8 \\
.1 \\
.1\end{array}$ & & $\begin{array}{l}417 \\
458 \\
336 \\
280 \\
313\end{array}$ & $\begin{array}{l}358 \\
250 \\
255 \\
220 \\
250\end{array}$ & $\begin{array}{r}10 \\
54 \\
0 \\
0 \\
14\end{array}$ & $\begin{array}{r}6 \\
15 \\
11 \\
10 \\
13\end{array}$ & $\begin{array}{l}91 \\
68 \\
93 \\
87 \\
81\end{array}$ & $\begin{array}{c}3 \\
.6 \\
.4 \\
.3 \\
.5\end{array}$ & $\begin{array}{l}710 \\
733 \\
547 \\
473 \\
419\end{array}$ & $\begin{array}{l}8.0 \\
8.0 \\
8.1 \\
8.2 \\
8.2\end{array}$ \\
\hline 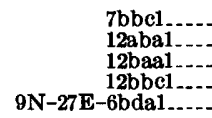 & $\begin{array}{l}26 \\
38 \\
41 \\
32 \\
42\end{array}$ & 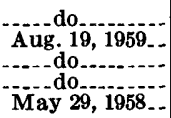 & 64 & $\begin{array}{r}106 \\
53 \\
56 \\
35\end{array}$ & \begin{tabular}{|l|}
38 \\
19 \\
48 \\
21
\end{tabular} & \begin{tabular}{rr|}
18 & 1 \\
& 1 \\
& 4 \\
15 & 10 \\
15 &
\end{tabular} & $\begin{array}{l}12 \\
49 \\
09 \\
-. . .\end{array}$ & $\begin{array}{l}412 \\
216 \\
460 \\
424 \\
152\end{array}$ & \begin{tabular}{r|}
2 \\
0 \\
6 \\
16 \\
0
\end{tabular} & $\begin{array}{l}50 \\
36 \\
20 \\
16 \\
53\end{array}$ & $\begin{array}{l}40 \\
11 \\
23 \\
15 \\
15\end{array}$ & & $\begin{array}{l}.8 \\
6.2 \\
2.2 \\
1.6\end{array}$ & $\mid$\begin{tabular}{c}
0.30 \\
\hdashline
\end{tabular} & \begin{tabular}{|r}
498 \\
\\
\end{tabular} & $\begin{array}{l}420 \\
210 \\
335 \\
175 \\
168\end{array}$ & $\begin{array}{r}79 \\
33 \\
0 \\
0 \\
44\end{array}$ & \begin{tabular}{r|}
8 \\
11 \\
24 \\
58 \\
16
\end{tabular} & $\begin{array}{l}76 \\
75 \\
87 \\
91 \\
62\end{array}$ & $\begin{array}{r}.4 \\
.3 \\
1.2 \\
3.6 \\
.5\end{array}$ & $\begin{array}{l}806 \\
419 \\
744 \\
694 \\
365\end{array}$ & \begin{tabular}{|l|}
8.3 \\
8.2 \\
8.3 \\
8.5 \\
7.9
\end{tabular} \\
\hline 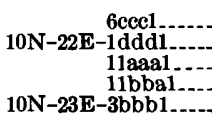 & $\begin{array}{l}40 \\
33 \\
32 \\
32 \\
32\end{array}$ & $\begin{array}{l}\text { Aug. 19, 1959. } \\
\text { July 10, 1958_.. } \\
\text { July 11, } \\
\text { July } 2,1958 \ldots \\
\end{array}$ & $-\ldots .$. & 50 & 23 & $\mid$\begin{tabular}{l|}
20 \\
6.2 \\
24 \\
22
\end{tabular} & 36 & $\begin{array}{l}308 \\
380 \\
414 \\
464 \\
320\end{array}$ & $\begin{array}{l}0 \\
0 \\
0 \\
0 \\
0\end{array}$ & $\begin{array}{l}16 \\
38 \\
50 \\
42 \\
53\end{array}$ & $\begin{array}{l}20 \\
15 \\
27 \\
7.4 \\
28\end{array}$ & & $\begin{array}{r}2.4 \\
33 \\
.0 \\
.0 \\
1.1\end{array}$ & & 251 & $\begin{array}{l}220 \\
376 \\
416 \\
382 \\
310\end{array}$ & $\begin{array}{r}0 \\
64 \\
76 \\
2 \\
48\end{array}$ & \begin{tabular}{r|}
26 \\
10 \\
3 \\
12 \\
13
\end{tabular} & $\begin{array}{l}84 \\
74 \\
79 \\
88 \\
73\end{array}$ & $\begin{array}{r}1.1 \\
.4 \\
.1 \\
.5 \\
.5\end{array}$ & $\begin{array}{l}519 \\
706 \\
706 \\
638 \\
617\end{array}$ & $\begin{array}{l}8.2 \\
7.5 \\
7.6 \\
7.8 \\
7.9\end{array}$ \\
\hline $\begin{array}{l}\text { 4bcc1 } \\
\text { 4dac1 } \\
\text { 8abcl } \\
\text { 9bec1 } \\
\text { 9cde1 }\end{array}$ & $\begin{array}{l}32 \\
31 \\
32 \\
32 \\
32\end{array}$ & $\begin{array}{c}\text { July } 1,1958 \ldots \\
\text { June } 30,1958 . \\
\text { July } 8,1058 \\
\end{array}$ & 64 & & $-\cdots$ & \begin{tabular}{|l|}
20 \\
47 \\
36 \\
37 \\
46
\end{tabular} & & $\begin{array}{l}426 \\
600 \\
292 \\
488 \\
510\end{array}$ & $\begin{array}{l}0 \\
0 \\
0 \\
0 \\
0\end{array}$ & \begin{tabular}{|l}
30 \\
38 \\
65 \\
44 \\
76
\end{tabular} & $\begin{array}{l}45 \\
62 \\
36 \\
46 \\
56\end{array}$ & & \begin{tabular}{c}
.0 \\
1.6 \\
\hdashline .1
\end{tabular} & $\begin{array}{c}.08 \\
.27\end{array}$ & $\begin{array}{l}419 \\
303\end{array}$ & $\begin{array}{l}400 \\
518 \\
280 \\
430 \\
476\end{array}$ & $\begin{array}{l}51 \\
26 \\
40 \\
30 \\
58\end{array}$ & $\begin{array}{l}10 \\
16 \\
22 \\
16 \\
17\end{array}$ & $\begin{array}{l}79 \\
79 \\
67 \\
78 \\
73\end{array}$ & $\begin{array}{l}.4 \\
.9 \\
.9 \\
.8 \\
.9\end{array}$ & $\begin{array}{r}707 \\
1,000 \\
609 \\
932 \\
887\end{array}$ & $\begin{array}{l}8.0 \\
7.7 \\
8.1 \\
8.0 \\
7.7\end{array}$ \\
\hline $\begin{array}{l}\text { 10cca1.... } \\
11 \mathrm{bbcl} . . . \\
11 \mathrm{dcc1}-. \\
12 \mathrm{cbb} 1 . . \\
13 \mathrm{ada} 1 . .\end{array}$ & $\begin{array}{l}32 \\
32 \\
32 \\
32 \\
48\end{array}$ & $\begin{array}{l}\text { do } \\
\text { July } 9,1958 \ldots \\
\text { June } 12,1958 . \\
\end{array}$ & & & 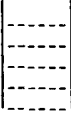 & \begin{tabular}{|l|}
15 \\
38 \\
8.5 \\
13 \\
20
\end{tabular} & 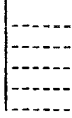 & $\begin{array}{l}\mathbf{4 4 4} \\
546 \\
376 \\
\mathbf{4 5 2} \\
\mathbf{2 4 4}\end{array}$ & $\begin{array}{l}0 \\
0 \\
0 \\
0 \\
0\end{array}$ & \begin{tabular}{|r|}
112 \\
54 \\
25 \\
38 \\
24
\end{tabular} & \begin{tabular}{|l}
20 \\
45 \\
4.8 \\
20 \\
18
\end{tabular} & & $\begin{array}{r}.0 \\
4.4 \\
.4 \\
.4\end{array}$ & 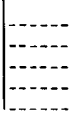 & \begin{tabular}{|r}
486 \\
\\
\end{tabular} & $\begin{array}{l}476 \\
488 \\
334 \\
410 \\
212\end{array}$ & $\begin{array}{r}112 \\
40 \\
26 \\
40 \\
12\end{array}$ & $\begin{array}{r}6 \\
14 \\
5 \\
6 \\
17\end{array}$ & $\begin{array}{l}72 \\
78 \\
87 \\
84 \\
78\end{array}$ & $\begin{array}{l}.3 \\
.7 \\
.2 \\
.3 \\
.6\end{array}$ & $\begin{array}{l}808 \\
860 \\
577 \\
654 \\
459\end{array}$ & \begin{tabular}{|l}
7.5 \\
7.7 \\
7.7 \\
8.1 \\
8.0
\end{tabular} \\
\hline
\end{tabular}




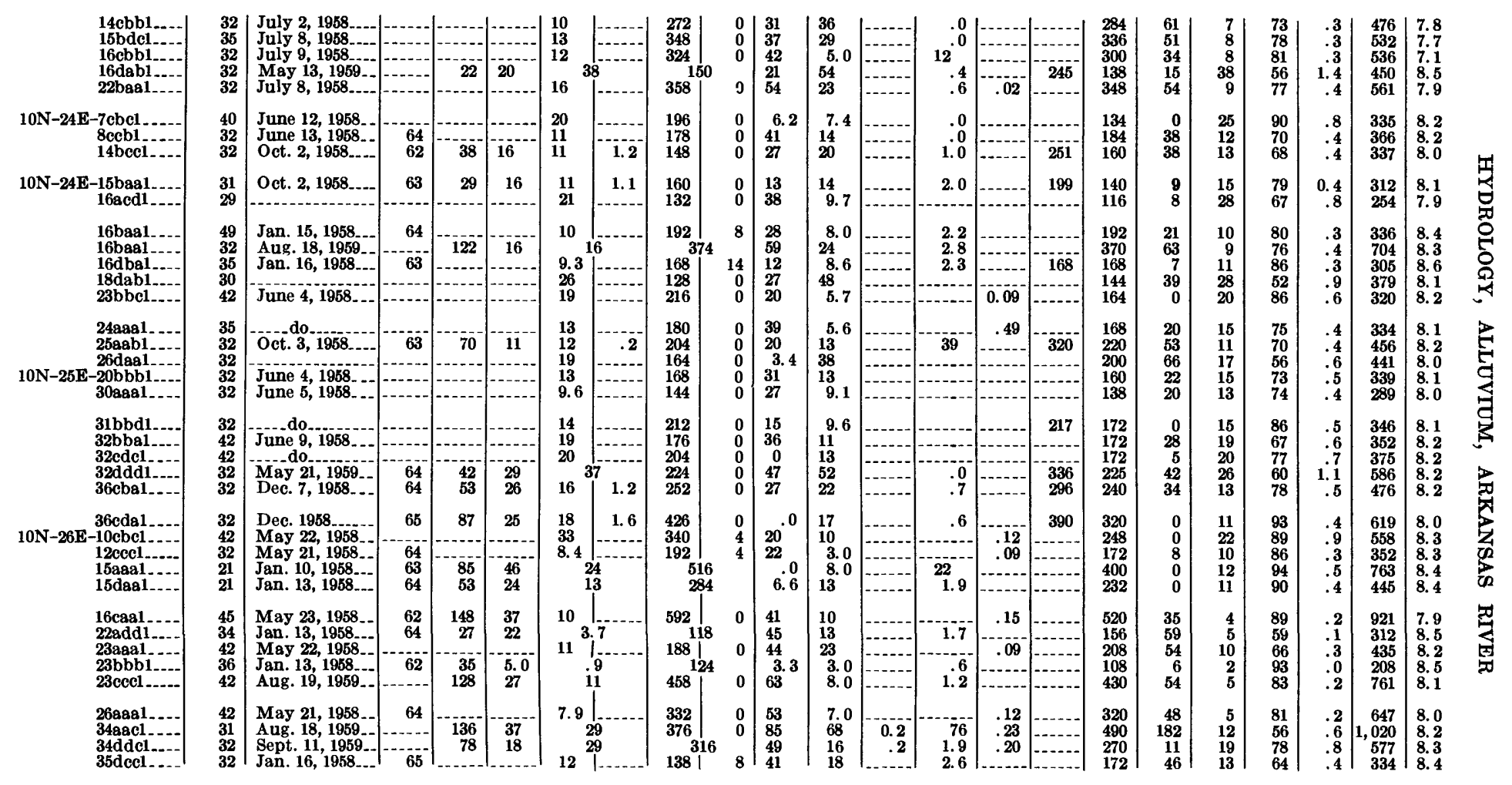


TABLE 6.-Chemical analyses of water from the alluvium along the Arkansas River between Muskogee, Okla., and Fort Smith, Ark.Continued

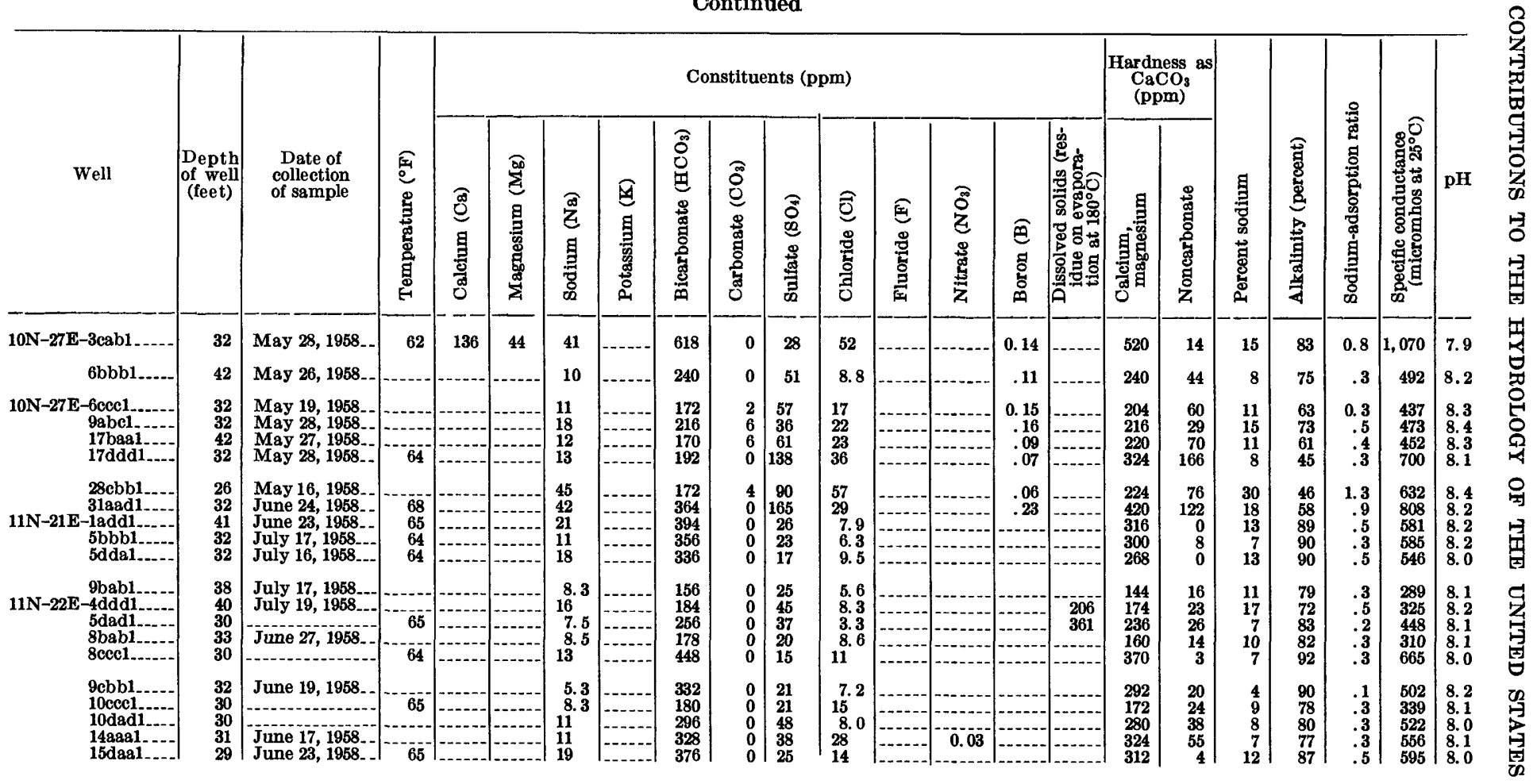




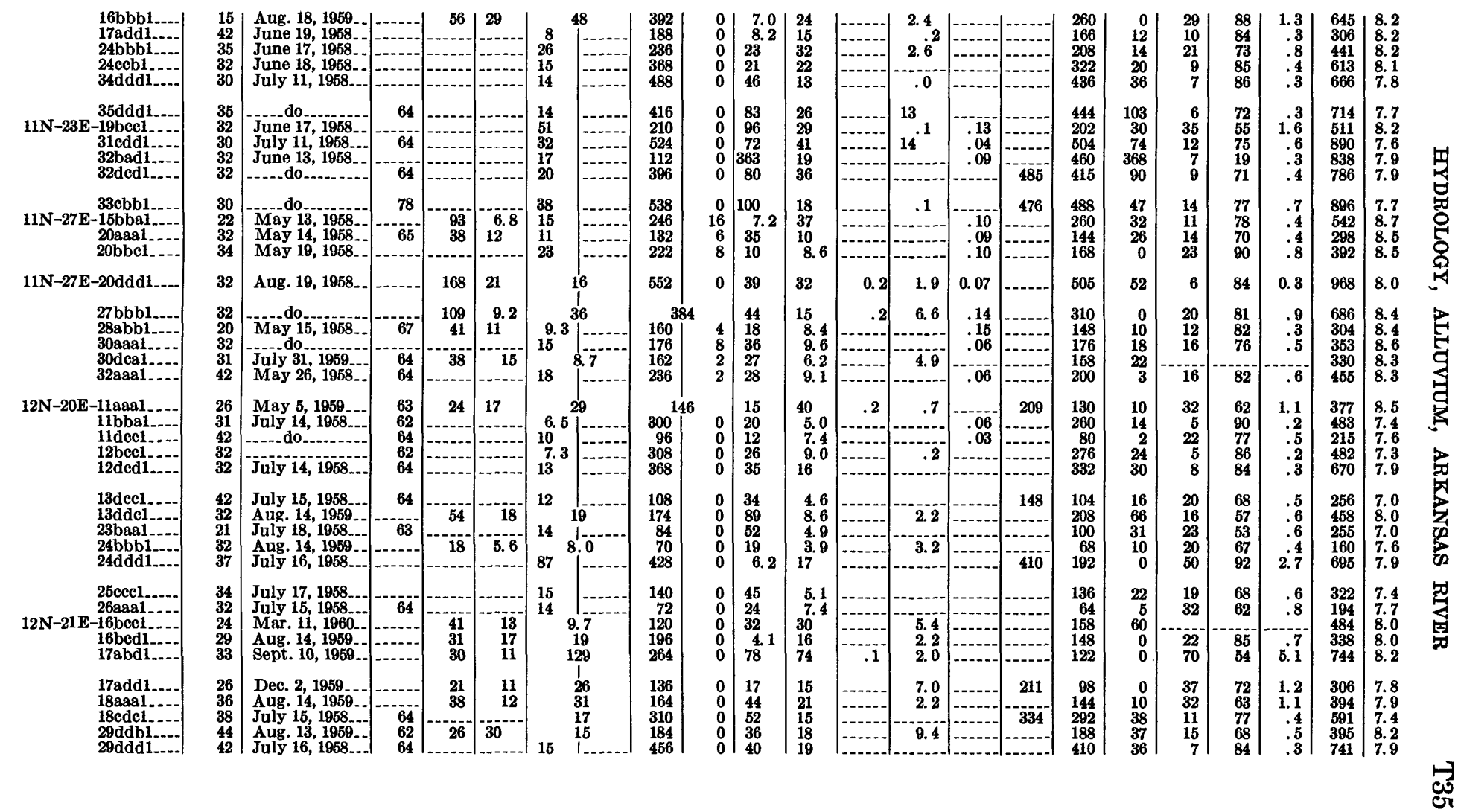


TABLE 6.-Chemical analyses of water from the alluvium along the Arkansas River between Muskogee, Okla., and Fort Smith, Ark.Continued

\begin{tabular}{|c|c|c|c|c|c|c|c|c|c|c|c|c|c|c|c|c|c|c|c|c|c|c|}
\hline \multirow{2}{*}{ Well } & \multirow[b]{2}{*}{$\begin{array}{c}\text { Depth } \\
\text { of well } \\
\text { (feet) }\end{array}$} & \multirow[b]{2}{*}{$\begin{array}{l}\text { Date of } \\
\text { collection } \\
\text { of sample }\end{array}$} & \multirow[b]{2}{*}{ 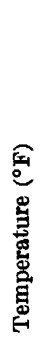 } & \multicolumn{12}{|c|}{ Constituents (ppm) } & \multicolumn{2}{|c|}{$\begin{array}{c}\mathrm{Hardness} \text { as } \\
\mathrm{CaCO}_{3} \\
(\mathrm{ppm})\end{array}$} & \multirow[b]{2}{*}{ 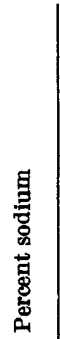 } & \multirow[b]{2}{*}{ 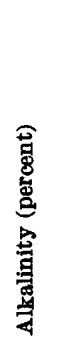 } & \multirow[b]{2}{*}{ 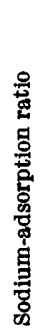 } & \multirow[b]{2}{*}{ 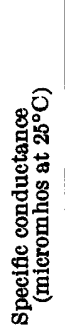 } & \multirow[b]{2}{*}{ pH } \\
\hline & & & & 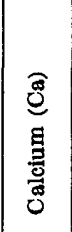 & 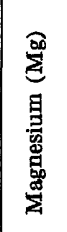 & 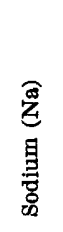 & 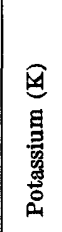 & 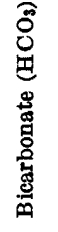 & 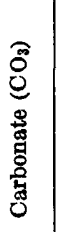 & 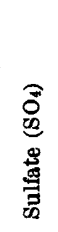 & 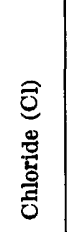 & $\begin{array}{l}\text { 国 } \\
\text { 总 } \\
\text { 总 }\end{array}$ & 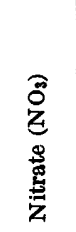 & 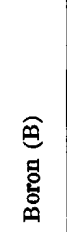 & 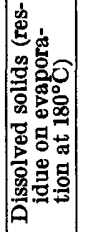 & 竭 & 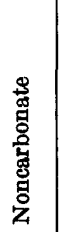 & & & & & \\
\hline $\begin{array}{l}\text { 30aaa1 } \\
\text { 31bbb1--- } \\
31 \mathrm{cbb} 1-- \\
32 \mathrm{bbb1}- \\
\text { 33ccb1 }\end{array}$ & $\begin{array}{l}37 \\
32 \\
42 \\
32 \\
32\end{array}$ & $\begin{array}{l}\text { July 17, } 1958 . \\
\text { July 16, 1958.- } \\
\text { July 11, } 1958 .\end{array}$ & \begin{tabular}{c}
64 \\
66 \\
\hdashline 63 \\
64
\end{tabular} & $\cdots$ & 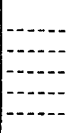 & $\begin{array}{l}8.7 \\
13 \\
14 \\
17 \\
16\end{array}$ & $\cdots$ & $\begin{array}{l}340 \\
192 \\
298 \\
340 \\
296\end{array}$ & $\begin{array}{l}0 \\
0 \\
0 \\
0 \\
0\end{array}$ & $\begin{array}{l}44 \\
50 \\
49 \\
33 \\
56\end{array}$ & \begin{tabular}{c|}
13 \\
4.66 \\
8.0 \\
23 \\
27
\end{tabular} & \begin{tabular}{l}
$-\cdots$ \\
$-\cdots$ \\
\hdashline- \\
\hdashline- \\
$-\cdots$
\end{tabular} & - & $\begin{array}{c}0.06 \\
-.0 \\
-y\end{array}$ & & $\begin{array}{l}324 \\
188 \\
276 \\
308 \\
304\end{array}$ & $\begin{array}{l}46 \\
30 \\
32 \\
30 \\
62\end{array}$ & $\begin{array}{r}6 \\
13 \\
10 \\
11 \\
10\end{array}$ & $\begin{array}{l}81 \\
73 \\
80 \\
81 \\
72\end{array}$ & $\begin{array}{r}0.2 \\
.4 \\
.4 \\
.4 \\
.4\end{array}$ & $\begin{array}{l}600 \\
395 \\
531 \\
603 \\
602\end{array}$ & $\begin{array}{l}\text { 8. } 0 \\
7.7 \\
8.0 \\
7.5 \\
8.0\end{array}$ \\
\hline $\begin{array}{r}2 a a a 1 \\
13 \mathrm{~N}-19 \mathrm{E}-2 \mathrm{cdc1} \\
3 \mathrm{3aaa1} \\
14 \mathrm{~N}-19 \mathrm{E}-24 \mathrm{abb1} \\
\text { 35baal }\end{array}$ & \begin{tabular}{l|}
38 \\
32 \\
39 \\
37 \\
37
\end{tabular} & \begin{tabular}{|c|} 
Aug. 14, 1959.- \\
\\
\end{tabular} & $\begin{array}{l}64 \\
63 \\
64 \\
63\end{array}$ & $\mid$\begin{tabular}{l}
$-\cdots-\cdot$ \\
\hdashline$-\cdots-$ \\
\hdashline$-\cdots$ \\
$-\cdots$
\end{tabular} & \begin{tabular}{|l|}
10 \\
\hdashline-1 \\
\\
\hdashline-1 \\
\end{tabular} & $\begin{array}{cc} & 1 \\
21 & \\
18 & \\
9.0 \\
9.4\end{array}$ & 53 & $\begin{array}{l}4 \\
364 \\
516 \\
500 \\
544\end{array}$ & $\begin{array}{l}0 \\
0 \\
0 \\
0\end{array}$ & $\begin{array}{r}2.9 \\
12 \\
45 \\
90 \\
198\end{array}$ & \begin{tabular}{c|}
28 \\
10 \\
7.2 \\
11 \\
6.1
\end{tabular} & 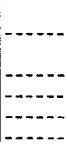 & 16 & $\begin{array}{r}0.04 \\
.10 \\
\end{array}$ & $|--702|$ & $\begin{array}{l}108 \\
280 \\
454 \\
500 \\
640\end{array}$ & $\begin{array}{r}0 \\
0 \\
31 \\
90 \\
194\end{array}$ & $\begin{array}{r}76 \\
14 \\
8 \\
4 \\
3\end{array}$ & $\begin{array}{l}90 \\
92 \\
86 \\
79 \\
68\end{array}$ & $\begin{array}{r}6.4 \\
0.5 \\
.4 \\
.2 \\
.2\end{array}$ & $\begin{array}{r}767 \\
565 \\
789 \\
879 \\
1,040\end{array}$ & $\begin{array}{l}8.3 \\
7.9 \\
7.4 \\
7.8 \\
7.4\end{array}$ \\
\hline
\end{tabular}




\begin{tabular}{|c|c|c|c|c|c|c|c|c|c|c|c|c|c|c|c|c|c|c|c|c|c|c|}
\hline 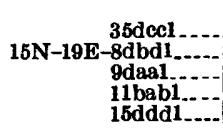 & $\begin{array}{l}34 \\
37 \\
26 \\
26 \\
29\end{array}$ & 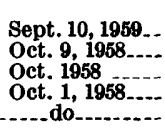 & $\begin{array}{c}- \\
67 \\
64 \\
63\end{array}$ & $\begin{array}{r}34 \\
139 \\
56 \\
22 \\
62\end{array}$ & \begin{tabular}{|l}
$3_{34}^{29}$ \\
9.8 \\
9.8 \\
28
\end{tabular} & $\begin{array}{l}13 \\
14 \\
24 \\
12\end{array}$ & $\begin{array}{r}1.6 \\
.9 \\
5.0 \\
1.3\end{array}$ & $\begin{array}{l}236 \\
520 \\
164 \\
168 \\
308\end{array}$ & $\begin{array}{l}0 \\
0 \\
0 \\
0 \\
0\end{array}$ & $\begin{array}{l}62 \\
48 \\
39 \\
11 \\
37\end{array}$ & $\begin{array}{l}22 \\
20 \\
22 \\
3.6 \\
4.0\end{array}$ & -- & $\begin{array}{r}.0 \\
9.3 \\
.5 \\
1.0 \\
.2\end{array}$ & $\mid$\begin{tabular}{c}
.23 \\
\hdashline .12 \\
\hdashline. .2 \\
\end{tabular} & $\begin{array}{l}320 \\
555 \\
274 \\
217 \\
335\end{array}$ & $\begin{array}{r}204 \\
\mathbf{4 8 5} \\
\mathbf{1 8 0} \\
\mathbf{9 2} \\
270\end{array}$ & $\begin{array}{c}10 \\
59 \\
46 \\
0 \\
18\end{array}$ & $\begin{array}{r}29 \\
6 \\
14 \\
35 \\
9\end{array}$ & $\begin{array}{l}67 \\
83 \\
65 \\
89 \\
85\end{array}$ & $\begin{array}{r}1.2 \\
.3 \\
.5 \\
1.1 \\
.3\end{array}$ & $\begin{array}{l}545 \\
876 \\
395 \\
292 \\
526\end{array}$ & \begin{tabular}{|l|}
8.1 \\
7.6 \\
8.1 \\
7.3 \\
8.0
\end{tabular} \\
\hline 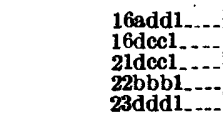 & $\begin{array}{l}\mathbf{2 3} \\
\mathbf{3 2} \\
\mathbf{3 0} \\
\mathbf{3 2} \\
\mathbf{3 0}\end{array}$ & $\begin{array}{l}\text { Oct. } 1958 \\
\text { Oct. 1, 1958- } \\
\text { Oct. } 2,1958 \\
\text { Aug. 14, 1959. } \\
\text { Oct. } 2,1958\end{array}$ & $\begin{array}{c}66 \\
-63 \\
-63\end{array}$ & $\begin{array}{l}42 \\
94 \\
96 \\
74 \\
67\end{array}$ & $\begin{array}{l}13 \\
11 \\
17 \\
23 \\
23\end{array}$ & $\begin{array}{l}16 \\
6.2 \\
12 \\
12\end{array}$ & $\begin{array}{l}1.0 \\
1.8 \\
.4\end{array}$ & $\begin{array}{r}160 \\
31 \\
36 \\
33\end{array}$ & 0 & $\begin{array}{l}38 \\
27 \\
14 \\
28 \\
15\end{array}$ & $\begin{aligned} 14 \\
4.5 \\
9.2 \\
4.6 \\
3.3\end{aligned}$ & .2 & $\begin{array}{l}1.8 \\
.4 \\
1.0 \\
1.2 \\
3.0\end{array}$ & .19 & $\begin{array}{r}238 \\
354 \\
369 \\
-302\end{array}$ & $\begin{array}{l}160 \\
280 \\
310 \\
300 \\
260\end{array}$ & $\begin{array}{r}29 \\
24 \\
8 \\
28 \\
0\end{array}$ & $\begin{array}{r}18 \\
5 \\
8 \\
3 \\
9\end{array}$ & $\begin{array}{l}68 \\
88 \\
91 \\
88 \\
92\end{array}$ & $\begin{array}{l}.6 \\
.2 \\
.3 \\
.1 \\
.3\end{array}$ & $\begin{array}{l}362 \\
548 \\
590 \\
515 \\
485\end{array}$ & $\begin{array}{l}8.1 \\
8.3 \\
8.3 \\
8.3 \\
8.4\end{array}$ \\
\hline $\begin{array}{l}\text { 24bbbl } \\
\text { 24bba1-- } \\
\text { 24ddd1- } \\
\text { 26bbbl- } \\
\text { 27bccl- }\end{array}$ & $\begin{array}{l}30 \\
24 \\
26 \\
30 \\
28\end{array}$ & $\begin{array}{l}\text { Oct. 3, 1958 } \\
\text { oct. 10, } \\
\text { Oct. 2, 1958-... }\end{array}$ & $\begin{array}{l}63 \\
64 \\
62 \\
63 \\
64\end{array}$ & $\begin{array}{l}64 \\
45 \\
98 \\
66 \\
43\end{array}$ & \begin{tabular}{|l}
24 \\
27 \\
13 \\
31 \\
26
\end{tabular} & $\begin{array}{l}19 \\
57 \\
14 \\
12 \\
9.3\end{array}$ & $\begin{array}{l}.8 \\
3.7 \\
1.5 \\
3.0 \\
2.9\end{array}$ & $\begin{array}{c}302 \\
32 \\
380 \\
290 \\
244\end{array}$ & $\begin{array}{l}0 \\
0 \\
0\end{array}$ & $\begin{array}{l}29 \\
42 \\
1.2 \\
32 \\
9.1\end{array}$ & $\begin{array}{c}9.3 \\
17 \\
6.7 \\
16 \\
2.6\end{array}$ & & $\begin{array}{r}6.0 \\
.6 \\
.2 \\
.7 \\
.6\end{array}$ & & $\begin{array}{l}335 \\
378 \\
442 \\
323 \\
225\end{array}$ & $\begin{array}{l}260 \\
224 \\
300 \\
290 \\
216\end{array}$ & \begin{tabular}{r|}
12 \\
0 \\
0 \\
52 \\
16
\end{tabular} & $\begin{array}{r}14 \\
35 \\
9 \\
8 \\
8\end{array}$ & $\begin{array}{l}84 \\
80 \\
97 \\
81 \\
94\end{array}$ & $\begin{array}{r}.5 \\
1.7 \\
.4 \\
.3 \\
.3\end{array}$ & $\begin{array}{l}514 \\
595 \\
707 \\
523 \\
383\end{array}$ & \begin{tabular}{|l}
8.4 \\
8.4 \\
8.2 \\
8.2 \\
8.2
\end{tabular} \\
\hline $\begin{array}{r}\text { 27dad1 } \\
\text { 28aaa1-..- } \\
\text { N-18E-35ddd1... }\end{array}$ & $\begin{array}{l}26 \\
30 \\
34\end{array}$ & $\begin{array}{l}\text { do } \\
\text { oct. } 7,1958 \\
\text { do-. }\end{array}$ & $\begin{array}{l}65 \\
64 \\
65\end{array}$ & $\begin{array}{l}35 \\
91 \\
99\end{array}$ & $\begin{array}{l}22 \\
25 \\
35\end{array}$ & $\begin{array}{l}12 \\
6.2 \\
11\end{array}$ & $\begin{array}{r}.8 \\
.9 \\
2.4\end{array}$ & $\begin{array}{l}160 \\
374 \\
252\end{array}$ & $\begin{array}{l}0 \\
0 \\
0\end{array}$ & $\begin{array}{l}26 \\
18\end{array}$ & $\begin{array}{l}2.8 \\
10^{.8}\end{array}$ & & $\begin{array}{r}3.1 \\
65\end{array}$ & & $\begin{array}{l}214 \\
341 \\
524\end{array}$ & $\begin{array}{l}176 \\
330 \\
390\end{array}$ & $\begin{array}{r}45 \\
24 \\
184\end{array}$ & $\begin{array}{r}13 \\
4 \\
6\end{array}$ & $\begin{array}{l}81 \\
93 \\
50\end{array}$ & $\begin{array}{l}.4 \\
.1 \\
.2\end{array}$ & $\begin{array}{l}365 \\
573 \\
758\end{array}$ & $\begin{array}{l}8.2 \\
7.9\end{array}$ \\
\hline
\end{tabular}


TABLE 7,-Maximum, minimum, and modal concentrations of chemical constituents in water from the alluvium between Muskogee and Fort Smith

[In parts per million]

\begin{tabular}{|c|c|c|c|c|c|c|c|c|c|c|c|c|c|c|}
\hline \multirow[t]{2}{*}{ County } & \multicolumn{2}{|c|}{$\begin{array}{l}\text { Sodium } \\
\text { (Na) }\end{array}$} & \multicolumn{2}{|c|}{$\begin{array}{c}\text { Bicar- } \\
\text { bonate } \\
\left(\mathrm{HCO}_{3}\right)\end{array}$} & \multicolumn{2}{|c|}{$\begin{array}{l}\text { Sulfate } \\
\left(\mathrm{SO}_{4}\right)\end{array}$} & \multicolumn{2}{|c|}{$\begin{array}{c}\text { Chloride } \\
\text { (Cl) }\end{array}$} & \multicolumn{2}{|c|}{$\begin{array}{l}\text { Nitrate } \\
\left(\mathrm{NO}_{3}\right)\end{array}$} & \multicolumn{2}{|c|}{ 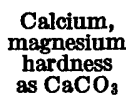 } & \multicolumn{2}{|c|}{$\begin{array}{c}\text { Specific } \\
\text { conductance } \\
\text { (micromhos } \\
\text { at } 25^{\circ} \mathrm{C} \text { ) }\end{array}$} \\
\hline & Max & Min & $\operatorname{Max}$ & Min & Max & Min & Max & Min & Max & Min & Max & Min & Max & Min \\
\hline \multirow{2}{*}{$\begin{array}{c}\text { Sequoyah... } \\
\text { Lo Flore.-. } \\
\text { Haskell- } \\
\text { Muskogee.-.- } \\
\text { Mode for } \\
\text { area..-.- }\end{array}$} & $\begin{array}{l}129 \\
155 \\
46 \\
153\end{array}$ & $\begin{array}{l}0.9 \\
9.3 \\
6.2 \\
4.1\end{array}$ & $\begin{array}{l}600 \\
618 \\
546 \\
560\end{array}$ & $\begin{array}{r}86 \\
132 \\
138 \\
70\end{array}$ & $\begin{array}{l}363 \\
199 \\
112 \\
198\end{array}$ & $\begin{array}{r}0.0 \\
21.0 \\
1.2\end{array}$ & $\begin{array}{r}100 \\
308 \\
56 \\
45\end{array}$ & $\begin{array}{r}0.5 \\
5.6 \\
4.8 \\
.8\end{array}$ & \begin{tabular}{r|}
22 \\
385 \\
33 \\
65
\end{tabular} & $\begin{array}{l}0.0 \\
.0 \\
.0 \\
.0\end{array}$ & $\begin{array}{l}520 \\
950 \\
504 \\
640\end{array}$ & $\begin{array}{r}96 \\
116 \\
138 \\
64\end{array}$ & $\begin{array}{l}1,000 \\
2,870 \\
1,040\end{array}$ & $\begin{array}{l}208 \\
254 \\
450 \\
160\end{array}$ \\
\hline & \multicolumn{2}{|c|}{16} & \multicolumn{2}{|c|}{200} & \multicolumn{2}{|c|}{25} & \multicolumn{2}{|c|}{8.5} & \multicolumn{2}{|c|}{0.8} & \multicolumn{2}{|c|}{22} & \multicolumn{2}{|c|}{500} \\
\hline
\end{tabular}

More than 90 percent of the water samples collected in the area are of the calcium, magnesium bicarbonate type. Calcium and magnesium hardness, expressed as $\mathrm{CaCO}_{3}$, ranges from 40 to $950 \mathrm{ppm}$. Of the two ions, calcium is dominant. The concentration of bicarbonate, which ranges from 70 to $618 \mathrm{ppm}$, comprises $80-90$ percent of the total anion concentration. The maximum concentrations listed for sodium, sulfate, chloride, and nitrate are not indicative of typical water in the alluvium. In general, they represent temporary and localized conditions, which are caused by seepage from bedrock or adjacent formations or by contaminated seepage from the land surface.

The principal uses of ground water in this area are for domestic and irrigation supplies.

The U.S. Public Health Service Drinking Water Standards (1962) state that the following chemical substances should not be present in a water supply in excess of the listed concentrations, if, in the judgment of the reporting agency and certifying authority, other suitable supplies are or can be made available.

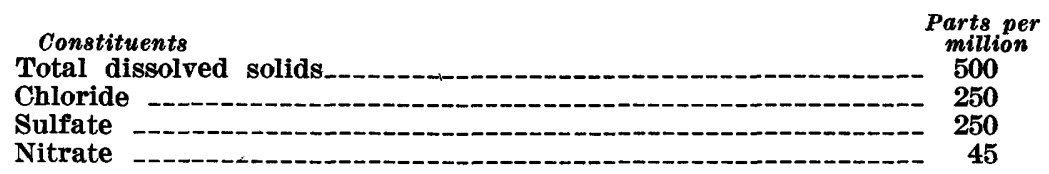

The chloride, sulfate, and nitrate contents of the water in only a few wells exceed the recommended maximum values. Wells in which the dissolved-solids content of the water exceeds $500 \mathrm{ppm}$ are more numerous.

Hardness is an undesirable characteristic of water used for domestic purposes. The water in most wells is very hard, exceeding $181 \mathrm{ppm}$.

Quality of water used for irrigation of crops must be of acceptable standards. Excessive sodium and dissolved solids may result in in- 
jury to crops. Because of the moderate to low sodium and dissolvedsolids contents, most of the water in the alluvium is within the general "excellent to good" and "good to permissible" classifications for irrigation use (Wilcox, 1948).

Intense or prolonged pumping of wells adjacent to the river may induce water of poor quality from the river to enter the alluvium. In some areas prolonged pumping during periods of drought may reduce the hydraulic head sufficiently to induce water of poor quality from the bedrock. Under these conditions the concentrations of sodium, chloride, sulfate, and dissolved solids in the water would increase and thereby impair the suitability of the water for beneficial use.

\section{EFFECT OF CHANGED RIVER CONDITIONS ON THE HYDROLOGIC SYSTEM OF THE ALLUVIUM}

The alluvial valley of the Arkansas River is a large hydrologic system in which the river, the alluvial deposits, and the bedrock under natural conditions are in hydraulic connection and in dynamic balance. The construction of navigational facilities on the Arkansas River will alter the natural river gradient to a series of stepped pools between each lock and dam. Ground-water levels in the alluvium will adjust to the changed boundary conditions by rising in most areas and lowering in others. A permanent change in the water level will alter the recharge and discharge relation of the alluvium. This change, where significant, will affect recharge by precipitation, discharge by seepage, discharge by evapotranspiration, water-level fluctuation, storage, and quality of the water in the alluvium. These changes in the alluvium are discussed briefly in relation to the change in water level and boundary cónditions.

Recharge by precipitation.-Recharge will decrease, by the amount of recharge rejected, where water levels are raised at or near the land surface. Recharge will increase, by the amount of recharge rejected presently, where present water levels at or near the surface are lowered. There will be no change in recharge where no recharge is rejected by changes in water levels.

Discharge by evapotranspiration.-Discharge will increase where water levels are raised to within the root zone of plants, or close enough to the surface to allow loss to the atmosphere. Discharge will decrease where present water levels, subject to evapotranspiration, are lowered. Discharge will not change where changes in water levels are beyond the effective reach of evapotranspiration.

Discharge by seepage.-Discharge will increase where water levels are raised and transmissibility is increased. Discharge will decrease 
where water levels are lowered and transmissibility is decreased. In most areas water levels will rise in the fine-grained material of the alluvium having low permeability, and transmissibility and discharge by seepage will not be increased significantly.

Water-level fluctuations. - Water-level fluctuations near the river are influenced primarily by the stage of the river. This influence decreases with distance from the river. Under changed river conditions the river will become a series of reservoirs that will maintain a nearly constant stage and thus stabilize ground-water fluctuations near the river. At a distance from the river, water levels fluctuate mainly in response to recharge and discharge. Generally, where water levels are raised, fluctuations of water levels are greater in magnitude and respond more quickly to recharge and discharge.

Storage.-Storage will change with adjustment in water levels. Where water levels are raised or lowered, storage in the alluvium will increase or decrease. In most areas between Muskogee and Fort Smith the water level in the alluvium will be raised to increase storage and the potential amount of water that can be withdrawn.

Quality of water.-Changes in the quality of water in the alluvium initially will be related to the altered quality of the river water. When the locks and dams are closed, temporary seepage of river water into the alluvium near the pools is to be expected. The distance of penetration of influent seepage will depend on the length of time it takes for the ground-water level to reach equilibrium with the new river level. After equilibrium and the hydraulic gradient toward the river are reestablished, the intruded river water will discharge into the alluvium.

Raising and lowering ground-water levels will cause some alteration in quality of water in the alluvium. Raising water levels will have the temporary effect of increasing the dissolved-solids content through the solution of the more soluble mineral constituents in the silts and clays in the upper part of the alluvium. As evapotranspiration increases there will be some concentration of mineral constituents in the upper zone, which will increase the mineral content of the water slightly. Lowering water levels will tend to confine the water to the coarser grained part of the alluvium, where less mineral matter is available for solution. Neither of these conditions will alter the general calcium, magnesium bicarbonate type water. In some areas a lowered water level will decrease the hydraulic head and permit increased seepage from adjacent or underlying bedrock formations, which generally will cause a deterioration in quality of the water. 


\section{SUMMARY AND CONCLUSIONS}

The important aquifer along the Arkansas River between Muskogee and Fort Smith is the alluvium. Its total thickness averages 42 feet and its saturated thickness about 25 feet. Recharge from rainfall is estimated to average 9 inches, or 67,000 acre-feet, per year. Most of the discharge is by seepage into streams and by evapotranspiration. Discharge by pumping for all purposes in 1962 was estimated at 1,700 acre-feet, which is insignificant in relation to the estimated 67,000 acre-feet of annual recharge and 450,000 acre-feet of storage in the alluvium.

Additional development of ground water is possible in large areas of the alluvium, which have the potential to yield as much as $600 \mathrm{gpm}$ of water to wells.

Ground water in the alluvium is principally of the calcium, magnesium bicarbonate type. The water is moderate in dissolved-solids content and hard, but is suitable for irrigation, domestic, and some industrial use.

Changes in the river system as a result of the navigation project on the Arkansas River will be reflected in changes in the recharge and discharge relation of the alluvium. These changes in most places will result in an increase in the amount of ground water available from the alluvium.

\section{SELECTED REFERENCES}

Duffin, R. B., 1963, Survey of irrigation in Oklahoma : Agricultural Extension Service, Oklahoma State University, 11 p.

Ferris, J. G., Knowles, D. B., Brown, R. H., and Stallman, R. W., 1962, Theory of aquifer tests: U.S. Geol. Survey Water-Supply Paper 1536-E, 174 p.

Huffman, G. G., 1958, Geology of the flanks of the Ozark Uplift: Oklahoma Geol. Survey Bull. 77, 281 p.

Jacob, O. E., 1950, Ground water, in Rouse, Hunter, ed., 1950, Engineering hydraulics: New York, John Wiley \& Sons, p. 321-385.

Knechtel, M. M., 1949, Geology and coal and natural gas resources of northern LeFlore County, Oklahoma: Oklahoma Geol. Survey Bull. 68, 76 p.

Oakes, M. C., and Knechtel, M. M., 1948, Geology and mineral resources of Haskell County, Oklahoma : Oklahoma Geol. Survey Bull. 67, 134 p.

Schoff, S. L., and Reed, E. W., 1951, Ground-water resources of the Arkansas River flood plain near Fort Gibson, Muskogee County, Oklahoma : Oklahoma Geol. Survey Circ. 28, 55 p.

U.S. Public Health Service, 1962, Drinking water standards, 1962: U.S. Public Health Service Pub. 956, 61 p.

Waterways Experiment Station, 1951, Geology of the lower Arkansas River alluvial valley, Pine Bluff, Ark., to mouth: U.S. Army Corps of Engineers Tech. Memo. 3-332.

Wenzel, L. K., 1942, Methods for determining permeability of water-bearing materials with special reference to discharging-well methods, with a sec- 
tion on direct laboratory methods and bibliography on permeability and lamniar flow, by V. C. Fishel: U.S. Geol. Survey, Water-Supply Paper 887, $192 \mathrm{p}$.

Wilcox, L. V., 1948, The quality of water for irrigation use: U.S. Dept. Agriculture Tech. Bull. 962, 40 p.

Wilson, C. W., Jr., 1937, Geology of the Muskogee-Porum district, Muskogee and McIntosh Counties, Oklahoma, with a chapter on carboniferous stratigraphy, by N. D. Newell: Oklahoma Geol. Survey Bull. 57, 184 p.

Wolman, M. G., and Leopold, L. B., 1957, River flood plains; some observations on their formation: U.S. Geol. Survey Prof. Paper 282-C, p. 87-109. 